\title{
VOORTREKKERHOOGTE 90 JAAR OUD
}

Kmdt Sophia du Preez*

\begin{abstract}
Following the occupation of Pretoria on 5 June 1900 during the Anglo-Boer War an area south of Pretoria became known as Roberts Heights. It was named after Field-Marshal Lord Roberts, Commander-in-Chief of the British forces in South Africa. On 26 May 1939 it was re-named Voortrekkerhoogte following the laying of the foundation stone of the Voortrekker monument.
\end{abstract}

\author{
Voortrekkerhoogte reflects its military heritage to this day as is evident from its many fine \\ historic buildings illustrated in the accompanying article.
}

\section{Voorgeskiedenis}

Op 4 Junie vanjaar is dit 90 jaar sedert die terrein wat Voortrekkerhoogte beslaan, die eeue van vergete bestaan afgeskud en die mens na hierdie heuwels geskiedenis gebring het. Toe die eerste blankes hulle in die omgewing van die Magaliesberg gevestig het, was daar min mense in die streek. Daar was volop grasvlaktes waar talle wildsoorte soos blesbokke, wildebeeste, renosters en zebras voorgekom het.

William Cornwallis Harris, die eerste blanke wat ooit die streek betree het, se 1836 beskrywings toon heelwat wild in 'n ongerepte natuur. ${ }^{1}$ Hierna het boere en handelaars die gebied betree. Die mense het meer geword. Die wild het minder geword. Op die vooraand van die twintigste eeu was die terrein waar Voortrekkerhoogte geleë is, tipies ongerepte, rooigras-bedekte bulte waaroorheen reisigers met wa en osse of te perd na en vanaf Krugersdorp en Potchefstroom gereis het. $^{2}$

Rondom die bulte was waterryke gebied geleë wat vanaf 1840 deur boere beset is. Die twee Bronkhorst broers, Lucas en Johannes, het hulle op Groenekloof en Elandspoort gevestig terwyl F.J.W. du Plessis hulle buurman op Dassiespoort was. In 1853 het Marthinus Wessel Pretorius, seun van die trekleier Andries Pretorius, laasgenojemde twee plase gekoop en Pretoria daarop aangelê.

Ten suide van die dorp was plase soos Swartkop en Doornkloof deur Daniel Erasmus en sy seun beset met 'n weduwee-skoonsuster, Susanna Margaretha (gebore Jacobs) op Rietvlei. 'n Ander weduwee, Helena Hennop, was ook onder die eerste intrekkers suid van Pretoria. ${ }^{3}$

Tussen hierdie plase het 'n lappie uitvalgrond as onvervreemde staatsgrond, op die rand van die dorp bly lê. Regtens was 'dit staatsgrond en tot die beskikking van reisigers wat daar kon uit- span en oornag, of dorpsbewoners wat dit as weiveld kon benut. ${ }^{4}$ Die staat het beskikkingsreg gehad op hierdie terrein waar later 'n militêre dorp verrys het.

\section{Staatsbesit of dorpsbesit?}

Die besitreg van dorpsgrond in die Suid-Afrikaanse Republiek (Transvaal) is bepaal deur 'n Volksraad Resolusie van 1858 soos gewysig op 12 Mei 1890 en weer in 1896. Artikel 1 lui soos volg:

"De Algemeene dorpsgronden van dorpen in deze Republiek blijven staatsgronden, doch zullen gebruikt kunnen worden door de dorpsbewoners, als ook ten dienste en gebruik van reizigers gesteld worden, voor zooverre er niet op andere wijze, op voordracht van den Uitvoerenden Raad, door den Eersten Volksraad reeds over is, of zal worden beschikt." ${ }^{15}$

Kragtens bogenoemde was die huidige Voortrekkerhoogte onvervreemde staatsgrond toe die Tweede Anglo-Boereoorlog op 9 Oktober 1899 uitgebreek het. Elf maande later het lord Roberts by wyse van ' $n$ proklamasie Transvaal geannekseer.

Die Transvaalse hoofstad het geval, maar die oorlog het voortgeduur. Dit was ' $n$ vreemde situasie, aangesien die val van ' $n$ hoofstad en anneksasie van ' $n$ gebied vir eeue die resep $v$ as vir die beëindiging van 'n oorlog. Onder aie omstandighede het Britse regsgeleerdes hulle regering afgeraai om hulself outomaties as erfgename van die SAR regering - toe te velde - te beskou. $^{6}$

Teen hierdie agtergrond het die militêre goewerneur gedurende die oorlogsjare wyslik besluit om nie summier aanspraak te maak op staatsgrond nie maar om liewer met die stadsvaders te 
onderhandel. Op die wyse is ' $\mathrm{n}$ president geskep waarna die stadsraad nie van hulle nuutverkrege reg wou afstand doen nie. Teen die einde van die oorlog het die stadsvaders hulself as die regmatige erfgename van onvervreemde grond rondom Pretoria beskou. So was ook die repie grond waarop Voortrekkerhoogte gebou is en wat onvervreemde staatsgrond was in gedrang. Dit is ook op oorlogtydse kaarte as "townlands" aangedui.

Die Britte se aanvanklike optrede het inderwaarheid beskikkingsmag aan die stadsraad toegeken waaroor hulle regtens nie beskik het nie maar op aangedring het. Vroeg in 1902 byvoorbeeld het 'n privaat maatskappy, Wiggings en Clark, by die militêre goewerneur aansoek gedoen om 'n langtermyn huurkontrak op dorpsgrond vir doeleindes van 'n steenmakery. Die stadsraad het dadelik die Britse owerheid se reg om so 'n ooreenkoms te sluit betwis. ${ }^{7}$

Teen die einde van die oorlog, met die SAR se 1896 wetgewing in hulle guns, het die Britse owerheid die stadsraad se aansprake begin betwis. ${ }^{8}$ Die stadsraad het onder meer geskerm vir tradisionele water- en weiregte maar het telkens gebots met die nuwe regeerders wat toe streng by the letter van die wet wou bly.

Sonder beskerming van die wet, moes ander metodes gevind word. In ' $n$ brief gedateer 17 Mei 1902 het die agerende stadsklerk, John S. van Reesema, hom op die empatie van Britse amptenare beroep:

\begin{abstract}
"Under the late Republican Government the inhabitants of Pretoria, in common with those of the other towns and villages of the Transvaal, were deprived of all, or of any, adequate Municipal Government, and were powerless to resist all the subsequent alienations of town and village land; but under British administration it is understood that no alienation or dimination of any of the town or village lands of the Transvaal will be allowed otherwise than by consent of the inhabitants and then only for their common good."
\end{abstract}

Die stadsraad wou, soos tydens die oorlog, steeds onderhandel, maar die Transvaal administrasie, met die reg in hulle guns, het op regsgeldige bewyse van besitreg aangedring. Laasgenoemde het alle onvervreemde grond as kroongrond beskou. Derhalwe het die stadsraad 'n kommissie aangestel wat bewyse moes vind vir hulle aansprake op besitreg van die soge- naamde dorpsgronde. Vir ruim twee jaar daarna is beraadslaag. In April 1903 het die stadsraad uit protes bedank, ${ }^{10}$ maar uiteindelik is die kwessie met wetgewing wat in 1904 uitgereik is, bevredigend besleg.

Volgens 'n spesiale ooreenkoms wat aangegaan is, is voorsiening gemaak vir dorpsgronde vir die gebruik van die plaaslike inwoners sowel as vir die behoeftes van die staat aan terrein wat geskik was vir doeleindes van landbounavorsing, polisiestasies, poskantore, militêre basisse, ens. Die besetting van Britse soldate van die gebied suid van die Kwaggasrante en noord van Swartkop is hiermee ook gemagtig. ${ }^{11}$

\section{Militêre terreinbehoeftes op die draai van die eeu}

Na die val van Pretoria op 5 Junie 1900 is Britse soldate op oop dorpsgebied ontplooi, geboue in die dorp as kantoorruimte benut en het offisiere woonhuise van afwesige inwoners betrek. Daar was onder andere militêre kampe by Kwaggasrand en op sportgronde in Pretoria-Wes, aan die voet van Meintjieskop waarop die Uniegebou tans troon en in Sunnyside op terrein waar later 'n onderwyskollege gebou is. Die hoofkantoor waar eers lord Roberts en later sy opvolger, lord Kitchener, ook gewoon het, was in George Heys se sierlike huis in Jacob Maréstraat, naamlik Melrose Huis. ${ }^{12}$

Dit is nie duidelik presies wanneer daar besluit is om 'n kantonnement suid van Pretoria te vestig nie. Omstandigheidsgetuienis dui op 'n datum waarskynlik in 1902 en alvorens die vredesooreenkoms op 31 Mei 1902 geteken is. Teen hierdie datum was daar reeds ' $n$ tentdorp ${ }^{13}$ en is daar met die stadsraad onderhandel oor vergroting van die grondgebied. Voordat vrede gemaak is, het Britse medici aanbeveel dat die Britse soldate in Pretoria op hoër liggende terrein gehuisves word. Pretoria was 'n waterryke streek wat ' $n$ ideale broeiplek vir muskiete was ook die anopheles, draer van malaria. ${ }^{14}$

Bestrydingsmaatreëls soos ons dit vandag ken, het nie bestaan nie. Lede van die Royal Army Medical Corps (RAMC) het hulle hande vol gehad met soldate wat malaria opgedoen het. Op 16 Junie 1902 was daar in Pretoria vyf militêre algemene hospitale, naamlik onderskeidelik No's 2, 7, 19 en 22 General Hospital, die Race Course Hospital en ook 'n Advance Depot Medical Stores en ander seksie van die RAMC. ${ }^{15}$ 
Gebrek aan standhoudende waterbronne het daarvoor gesorg dat, na sestig jaar van blanke nedersetting, die gebied suidwes van Pretoria steeds onbewoond was. Dieselfde faktor was verantwoordelik vir die besluit om 'n kantonnement juis op die terrein te vestig.

Watervoorsiening aan die gebied was afhanklik van ' $n$ toevoersisteem vanaf die Fonteinedal op die plaas Groenkloof. Die militêre owerheid het tevergeefs probeer om beheer te verkry oor die 2 morg 422 roede waaroorheen die waterleiding gestrek het. Hulle moes tevrede wees met 'n onderneming van die stadsraad om aan al hulle watervoorsieningsbehoeftes te voldoen. ${ }^{16}$

Die kantonnement is Robertshoogte (Roberts Heights) genoem, na die man wat die Britse vlag op 5 Junie 1900 in 'n swak verdedigde Pretoria gehys het. Die vorige dag het hy vanaf Swartkop se kruin die geveg om besit van die SAR se hoofstad hanteer. ${ }^{17}$ Dit is dus moontlik dat hy daarna met sy verewaentjie deur die huidige Voortrekkerhoogte gereis het om te oornag in die omgewing waar later ' $n$ kantonnement met sy naam verrys het.

Daar is diegene wat beweer dat die Britse generaal die nag van 4 Junie 1900 op die terrein wat later sy naam gedra het, oornag het, dieselfde nag wat Proklamasieheuwel sy naam gekry het.

Wat ons wel weet is dat It-kol H. de B. de Lisle met sy twee berede infanterie korpse teen $16 \mathrm{~h} 45$ die heuwel later bekend as Proklamasieheuwel, beset en op 4 Junie daar oornag het. Van hier is 'n Wes-Australiese offisier, It W.W. Russell Watson, met ' $n$ wit vlag gestuur na kommandant-generaal Louis Botha om in Roberts se naam oorgawe te eis. Botha se sekretaris, C.G.S. Sandberg, en kmdt Sarel Oosthuizen is saam met die Australiese offisier eers na De Lisle en toe na Roberts. Al wat Sandjie (soos Botha hom graag genoem het) later kon onthou was die tyd, middernag, maar waar Roberts se verewaentjie gestaan het kon hy nie verduidelik nie en sal ons nou nooit weet nie. ${ }^{18}$

Teen 1905 is 'n totaal van 2001 morg 73 roede suid van Pretoria vir militêre doeleindes afgestaan. Dit was nadat 6 morg 167 roede spesiaal op versoek van lord Kitchener by die oorspronklike terrein gevoeg is. Hy het naamlik aangevoer dat die bestaande terrein nie voldoende was om ook huisvesting vir die bevelvoerende generaal te akkommodeer nie. Voor die toevoeging was die kantonnement se oosgrens net oos van waar Vesting geleë is.

Aanvanklik is gevra dat 'n perseel op die plaas Groenkloof net oos van die Johannesburgpad en min of meer waar die kleingeweerskietbaan onderkant die Voortrekkermonument tans is, vir die doel beskikbaar gestel word. Hierteen is besware ingebring. Ongeokkupeerde gebied tussen die kantonnement en Groenkloof is toe vir die oprigting van die woonhuis toegestaan. ${ }^{19}$ (Sien kaart.)

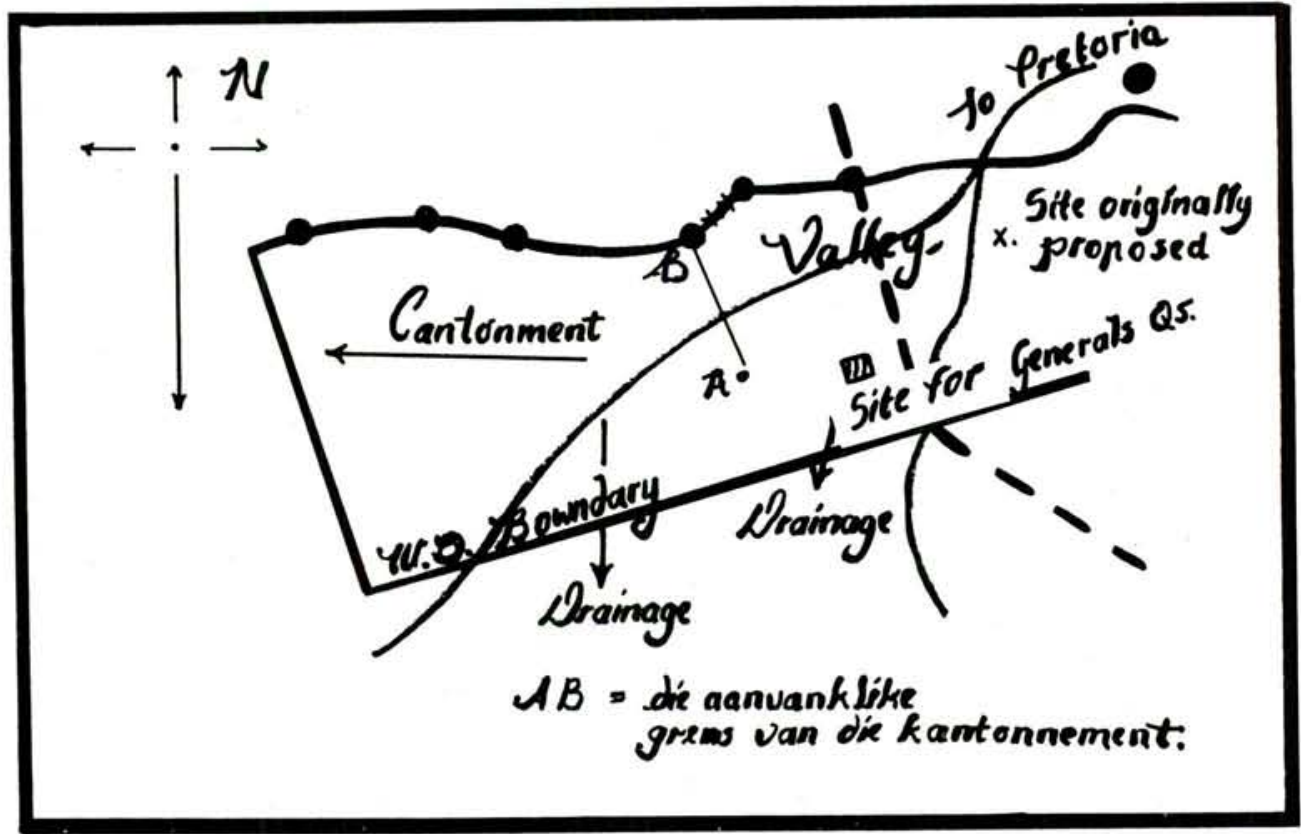

Hierdie kaart is 'n getroue weergawe van 'n kaart wat gebruik is tydens die onderhandelinge om uitbreiding van die kantonnement se terrein in 1902. 
Daar kon nie bewyse gekry word dat die voorafvervaardigde en ander geboue op Robertshoogte gedurende die oorlog gebou is nie. Volgens omstandigheidsgetuienis wil dit voorkom asof alles eers na die oorlog gebou is. Tydens die oorlog was die Royal Engineers druk besig met die bou van onder andere sink-en-houtkonstruksie blokhuise. ${ }^{20}$ Aangesien daar aan die einde van die oorlog steeds blokhuislinies onder konstruksie was, val dit te betwyfel of die oprigting van woonhuise voorrang sou geniet het bo die bou van blokhuise.

Daar is ' $n$ ander belangrike feit. Nadat hy as bevelvoerder aangestel is, is Kitchener in Desember 1900 en daarna gereëld tot so laat as Maart 1902 deur die Britse Secretary of War vermaan om uitgawes te besnoei. In die praktyk het dit beteken dat hy nie maklik koste aangegaan het nie. ${ }^{21}$

'n Goeie voorbeeld van sy besuinigingstrategie was akkommodasie vir perde. Nadat die konvensionele fase van die oorlog verby was, het Kitchener besef dat spoed ' $n$ bepalende faktor in die oorlog geword het. Aanvanklik het die Britte op getalsoorwig staatgemaak om Boeremagte te omsingel en uit te wis. ' $n$ Boer te perd was egter mans genoeg teen heelwat voetsoldate. Kitchener het toe besef dat sukses te velde vir hom in spoed geleë was. Hiervoor was perde nodig en het hy uiteindelik die konsep byna vervolmaak met sy "flying columns" wat hom instaat gestel het om Boere te verras.

Die perde wat van oor die hele wêreld ingevoer is, het egter ' $n$ kort lewensduur in Suid-Afrika beleef. Perdesiekte was die grootste enkele probleem. Dit kon oorbrug word deur goeie stalle vir perde daar te stel. Om koste te bespaar was Kitchener egter tot aan die einde van die oorlog huiwerig om permanente akkommodasie vir perd of mens te bou. ${ }^{22}$

Die oorlog het aanvanklik 'n groot uittog van stedelinge tot gevolg gehad. Derhalwe was akkommodasie vir offisiere en amptenare aanvanklik nie 'n probleem nie. Nadat die Witwatersrand se goudmyne weer in 1901 produksie hervat het, het behuising skaarser geword. Bewoners het teruggekeer en staatsamptenare is ingevoer as gevolg waarvan daar teen 1902 ' $n$ groot woningnood geheers het. ${ }^{23}$

Ten opsigte van die skaarste aan behuising in Johannesburg is derhalwe op 8 April 1902 besluit op "good temporary iron and wood houses, which, in view of the deficiency of buildings might be erected for use under rental of Civil Servants..." Tot op hede is hierdie die vroegste bewys dat die Britse owerheid voorafvervaardigde behuising in Transvaal ingevoer het. Soortgelyke konstruksies het ook op Potchefstroom, Heidelberg en Middelburg verrys. ${ }^{24}$

Bouwerk by die Pretoria kantonnement het stadig gevorder. ' $n$ Jaar nadat die oorlog ten einde geloop het, het die Royal Engineers berig dat, "Owing to the Cantonments not being yet ready for occupation, the establishments (that is the Welsh Regiment at the east end of Arcadia and the 24th Company ASC Transport camp, stables and shops north of the cemetry in Pretoria West) cannot be removed before the 14 th inst. the date fixed by ordinance no 38 for the evacuation by the military of private \& municipal lands." 25

Die huis van die bevelvoerende generaal ('n permanente konstruksie) was eers in 1903 voltooi, maar intussen is talle voorafvervaardigde konstruksies opgerig.

\section{Militêre geboue uit Indië?}

Talle navorsers het sedert die tweede wêreldoorlog probeer om te bepaal wat feit en wat fiksie is aangaande die herkoms van voorafvervaardigde geboue op Voortrekkerhoogte en plekke soos genl J.C. Smuts se huis op Irene. ${ }^{26}$ Sý huis was oorspronklik ' $n$ offisiersmenasie vir Britse offisiere wat op Middelburg gestasioneer was en wat hy later gekoop en op Irene opgerig het.

Ou inwoners van Voortrekkerhoogte het geglo dat die talle voorafvervaardigde geboue wat in die kantonnement opgerig was, uit Indië afkomstig was. Dit is moeilik om te bepaal waar hierdie verhaal sy oorsprong het, aangesien verskeie navorsers sedert Wêreldoorlog II onsuksesvol gesoek het na bewyse hiervoor. ${ }^{27}$

Op sinkplate wat in die konstruksies gebruik is, verskyn merke waaruit dit duidelik is dat die materiaal via Delagoabaai (tans Maputo) verskeep is. Dit is moontlik dat hierdie feit tot die aanname gelei het dat goedere uit Brittanje by ander Suid-Afrikaanse hawes ontskeep is en dat goedere uit Delagoabaai dus vanaf Indië afkomstig was. Die sinkplate toon twee fabrikate, naamlik "IXL" en "EMU" wat beteken dat hulle in Wolverhampton naby Birmingham in Engeland vervaardig is terwyl houtwerk van huise wat in 
Jacobus Naudéstraat staan, afkomstig is van Hull, aan die Humberrivier in Engeland. ${ }^{28}$

Daar word aangevoer dat die voorafvervaardigde konstruksies vir Indië bestem was en toe hier te lande gekom het, of uit Indië hierheen verskeep is. Laasgenoemde teorie strook nie met die feit dat die Britte steeds Indië beset het en dus die materiaal daar kon benodig nie. Trouens, Lord Kitchener was in groot haas om die oorlog in Suid-Afrika te beëindig omdat hy bang was iemand anders raap die bevelspos in Indië voor sy neus weg. ${ }^{29}$

By oorweging van hierdie herkoms teorie, is daar twee belangrike faktore wat nie uit die oog verloor moet word nie. In die eerste plek was dit nie ongewoon om goedere vanaf Brittanje via Delagoabaai na Transvaal te versend nie. Gedurende die eerste vyf maande van 1903 was uit 'n totale monitêre waarde van $£ 9762366$ se invoergoedere uit Brittanje £1536628 via Delagoabaai ingevoer. ${ }^{30}$

' $n$ Verdere belangrike punt om te onthou is die feit dat voorafvervaardigde konstruksies teen die einde van die vorige eeu ' $n$ algemene verskynsel was en nie uitsluitlik vir militêre gebruik in Indië vervaardig is nie.

Soos die oudste huise herinner ook die oudste straatname (talle is later vervang met ander) aan die eerste bewoners wat aan Voortrekkerhoogte vanaf 1902 tot 1904 sy basiese uitleg gegee het. Daar was Cavalry Road, Engineer Road, Artillery Road, Transport Road naby die stasie, Institute Road agter die huidige SA Leërkollege en twee strate genoem ter ere van die eerste bevelvoerende generaal nadat vrede gesluit is naamlik Neville- en Lyttelton Roads. Dan is daar die eenhede waarvan soldate hier diens gedoen het en wat op soortgelyke wyse vereer is, soos die Royal Welsh Fusiliers, The Kings Own Lancaster en die Prince of Wale's Leinster Regiment. ${ }^{31}$

\section{Van Britse kantonnement Roberts Heights tot Univerdedigingsmag se Voortrekkerhoogte}

Tydens Wêreldoorlog I is die meeste Britse soldate uit Suid-Afrika onttrek. Die basisse wat die Britte hier agtergelaat het, is na die oorlog amptelik aan die Unieregering geskenk. Om voorsiening te maak vir die oorname is Wet no 33 van 1922, getiteld "Verdediging begiftigings eigendom en rekening wet" gepasseer.
In die genoemde wet is ook die kantonnement genoem saam met die grondgebied waarop die generaalswoning gebou is, ' $n$ skietbaan op die plaas Groenkloof, die pompstasie op Groenkloof en die artillerie barakke in Pretoria. Laasgenoemde (tans Verdedigingshoofkwartier) se oordrag was terugwerkend vanaf 1 Oktober 1914 en die res vanaf 1 April 1921 van krag.

Die grondgebied met alle verbeteringe was gratis geskenk. Die wet het selfs klousules bevat wat daarvoor voorsiening gemaak het dat geen gelde betaalbaar was ten opsigte van oordragkoste, kaarte, hereregte, registrasiefooie of seëlregte nie. Die enigste sprake van vergoeding verbonde aan hierdie militêre besittings is ' $n$ staaltjie. Volgens oorlewering is die SA Leërkollege kwansuis vir drie biere aan die drie Britse onderhandelaars verruil. ${ }^{32}$

Robertshoogte of te wel die eg Britse Roberts Heights, gebore uit 'n Britse oorlog, gebou vir Britse bevelhebbers, was hierna amptelik 'n besitting van die Suid-Afrikaanse regering. Die oorlog was verby, die Britse bevelhebbers weg en les bes moes sy naam ook verander.

Om name te verander is nie ' $n$ nuwe giertjie nie. Trouens, baie van die eerste nedersetters in Suid-Afrika het hier geland met Latynse agtervoegsels aan hulle pragtige Hollandse name. Herman het as Hermanus, Jacob as Jacobus en Stefan as Stefanus geboet vir hulle ouers se modebewustheid.

So ' $n$ wind van verandering het met die Ossewa Trek deur Suid-Afrika gewaai 'n eeu na die Groot Trek van 1838. Landswyd het patriotisme weerklank gevind in 'n verskeidenheid vorme. Gedenkstene is opgerig, osse en wa se spore verewig in konkreet en straatname soos Eeufeesweg is geskep. Sommige Suid-Afrikaners het die fees in die huis gesleep en babatjies vir die res van hulle lewens geketting aan die Groot Trek met name soos Eeufesia en Ossewania Kakebenia! ${ }^{33}$

Teen dié agtergrond is dit verstaaribaar dat ' $n$ geslag wat die grootste monument in Suid-Afrika beplan en gebou het, nie aan die voet van die Voortrekkermonumentkoppie 'n militêre dorp met ' $n$ Britse naam en assosiasies onveranderd kon laat nie. Op 15 Desember, vooraand van 1938 se Geloftedag, is dit tydens 'n menasieaand by die kollege aangekondig deur die waarnemende Minister van Verdediging, oudAnglo Boereoorlog generaal en 1914 rebel, genl 
J.C. Kemp. ${ }^{34}$ Volgens kmdt-genl Klopper het dit op aanbeveling van die plaaslike bevelvoerder geskied $^{35}$ Kragtens Goewermentskennisgewing 708 van 26 Mei 1939 het Robertshoogte amptelik Voortrekkerhoogte geword.

Die geskiedenis van Voortrekkerhoogte is nou sowat negentig jaar oud. Die bouers aan wat aanvanklik Roberts Heights genoem is, het nie met die oog op permanensie gebou nie, maar ook hulle tydelike konstruksies het 'n erfenis aan Victoriaanse boukuns gelaat.

Baie van die oorspronklike voorafvervaardigde geboue is met die verloop van tyd verkoop aan die Suid-Afrikaanse Spoorweë en Hawens, Polisie en Gevangenisdiens. Sommige is gesloop. Baie is gedurende Wêreldoorlog II verskuif na krygsgevangene kampe terwyl 'n aantal ook deur brande verwoes is. ${ }^{36}$ Die eerste bakens is vinnig besig om te verdwyn. Tog staan daar nog mooi voorbeelde wat uit die ontstaansgeskiedenis van Voortrekkerhoogte dateer.

\section{SA Garrison Institute}

Die oudste permanente konstruksie op Voortrekkerhoogte is op die perseel van die SA Leërkollege geleë. Die gekapte klip gebou het 'n interessante ontstaansgeskiedenis. Tydens die Tweede Anglo-Boereoorlog het verskeie militêre eenhede in en om Pretoria oor klubfasiliteite beskik wat 'n batige saldo opgebou het. Een klub het met 'n wins van $£ 20000$ gespog. Aan die einde van die oorlog het lord Kitchener bereken dat indien hy hierdie winste onder sy soldate moes verdeel, elkeen oor drie sjielings en vier pennies (sowat 70 sent) sou beskik. Derhalwe het hy beslis dat winste aangewend moes word om fasiliteite vir die Britse garnisoen, wat in SuidAfrika gestasioneer sou word, te skep. Vir die doel is 'n terrein gekies naby 'n pan wat ná somerreëns gewemel het van wilde eende. ${ }^{37}$

Op 12 Junie 1902 en enkele dae voor sy vertrek uit Pretoria het Lord Kitchener die hoeksteen van die SA Garrison Institute gelê, die oudste gebou op die terrein wat vandag as die SA Leërkollege bekend staan. Een gedeelte van die gebou is gebruik vir die stoor van voorraad terwyl 'n groot lokaal (tans 'n eetsaal) afgesonder is vir die hou van kerkdienste.

Die eerste wêreldoorlog het die ontrekking van die Britse garnisoen meegebring waarna die Unieverdedigingsmag die fasiliteite op Roberts- hoogte oorgeneem het. Dit was die begin van 'n era waarin die statige gebou vir 'n verskeidenheid doeleindes benut is. Daar is sprake van Duitse krygsgevangenes wat hier aangehou is. Tydens Wêreldoorlog I is ook pasiënte hier gehospitaliseer en daarmee 'n president geskep wat herhaal is om vir die talle pasiënte tydens die groot griepepidemie van 1918 akkommodasie te skep. ${ }^{38}$ Tydens Wêreldoorlog II het Italiaanse krygsgevangenes hulle deel as bouers en messelaars bygedra en akkommodasie op die terrein aansienlik uitgebrei.

Vroeg in die jare twintig is besluit om die Unieverdedigingsmag se "SA Military Schools" vana1 Potchefstroom en Bloemfontein na Robertshoogte te verskuif, daarmee ook die rol van die gebou van die SA Garrison Institute, voorloper van die teenswoordige SA Weermag Instituut, of SAWI, soos dit by elke soldaat bekend staan. Die SA Militêre Kollege is in 1923 gestig en het op verskeie terreine opleiding verskaf, byvoorbeeld liggaamlike opvoeding, wapenopleiding, ens. ${ }^{39}$

Vir bykans negentig jaar gedy soldatelewe agter die sandsteen front: winkel, kerk, krygsgevangenekamp, hospitaal, eetsaal, kroeg en lesinglokaal - 'n belangrike baken vir alle soldate wat hier gedien het.

\section{Herehuis vir 'n generaal}

'n Ander permanente konstruksie wat oor bietjie meer as 'n dekade 'n eeu oud sal wees, is die gebou wat tans die SA Lugmag se Offisiersmenasie huisves, die sogenaamde Head Quarters House. Die gebou is aanvanklik opgerig as woonhuis vir generaal sir Neville Lyttelton wat na afloop van die Tweede Anglo-Boereoorlog in bevel van Britse Magte in Suid-Afrika was.

Hierdie gebou het verrys op terrein oos van die aanvanklike grense van die kantonnement wat lord Kitchener spesiaal vir die doel beding het, soos hierbo beskryf. (Sien kaart.) Die eerste bewoner, Lyttelton, het in Desember 1903 sy intrek in die huis geneem. Hiervan het hy later soos volg vertel:

"On our first night we were welcomed by a heavy hailstorm which.broke some fifty panes of glass. The house was designed by Herbert

Baker, the well-known architect and we had our own furniture out from England." 40

Sy meubels is later deur die Britse War Office oorgeneem sodat hulle nie nodig gehad het om 
'n meubeltoelaag aan Lyttelton se opvolgers te betaal nie.

Lyttelton is in Januarie 1905 verplaas en opgevolg deur genl sir Henry Hildyard, wat op sy beurt in April 1908 opgevolg is deur Lord Methuen, wat tot 1912 die pos - en andere - in SuidAfrika beklee het. ${ }^{41}$ Wat onmiddellik hierna met die gebou gebeur het, kon nie bepaal word nie, maar in Februarie 1914 is die woonhuis met alle buitegeboue verhuur aan A.G.G. Mylrea wat sy melkery hier gevestig het. Huurgeld is aan die War Department betaal.

Hier loop die verhaal weer dood tot 28 Februarie 1921. Op die datum het die destydse Direkteur Lugdiens, Pierre van Reyneveld per brief gevra dat Head Quarters House as hoofkwartier aan die SA Lugdiens toegesê word. In daardie stadium het nonne ' $n$ crèche daar gehad maar die gebou in Maart 1921 ontruim. Daar kon nie bepaal word presies wanneer die Lugdiens daar ingetrek het nie. Die gebou was vanaf 1 April die jaar in besit van die Unieverdedigingsmag en op 29 Julie die amptelike adres van die Lugdiens. Die hoofkwartierpersoneel, fotografiese-, bewapening- en radioseksies was op die eerste vloer terwyl die grondvloer omskep is in 'n offisiersklub vir lugdiensoffisiere. ${ }^{42}$

\section{ADC Cottage}

'n Interessante woonhuis wat op die perseel gestaan het, was die sogenaamde ADC kothuis, waar die aides-de-camp van die Britse bevelvoerders gehuisves was. Dit was 'n voorafvervaardigde konstruksie. Vanaf 1926 tot op die vooraand van Wêreldoorlog II het die latere genl K.R. van der Spuy die huis bewoon en na hom die persoonlike vlieënier van die Minister van Verdediging. Die baie bekende akteur, kdoor Alex Heyns het die huis tot 1973 bewoon. In 1980 is hierdie bekende baken in Voortrekkerhoogte deur ' $n$ brand verwoes.

\section{Ander geboue op die perseel}

Die Servants Quarters is baie lank verhuur as woning. Daarom is dit ook later van 'n badkamer voorsien. Die eerste inwoner vanaf 1 November 1922 was sers R.D. Scott, lid van die South African Mounted Rifles. Op 15 April 1923 het 'n seiner dit oorgeneem tot J. Hollenbach, bestuurder van die Pretoria Garrison Institute ingetrek en tot April 1930 daar gewoon het. Eers daarna het die eerste lid van die Lugdiens, vlug-sers E.C. Euckermann vier jaar daar gewoon. Militêre personeel het tot 1937 daar gewoon waarna dit aan burgerlikes verhuur is. Dit het gebeur nadat die kwartiermeester-generaal verklaar het dat die gebou nie geskik was as permanente woning vir SA Weermag personeel nie.

Die motorhuis, store en kamers vir anderskleuriges is tot die beskikking gestel van die Pretoria Garrison Institute tot in 1938, terwyl die Grooms Quarters vir ' $n$ minimale bedrag aan burgerlikes verhuur is.

Beide die tuinier se woonhuis en waghuis is bewoon deur personeel van die SA Lugdiens totdat eersgenoemde op 28 Augustus 1956 en laasgenoemde twee jaar later gesloop is. Afgesien van bogenoemde geboue was daar les bes ook ' $n$ washuis op die perseel. ${ }^{43}$ Met bogenoemde feite in gedagte is dit verstaanbaar waarom Lord Kitchener dit nodig geag het om so 'n groot terrein vir die gebruik van die bevelvoerende generaal te beding!

\section{District House}

'n Tweede baie bekende woonhuis op Voortrekkerhoogte is Vesting, 'n groot enkelverdieping voorafvervaardigde gebou en waarskynlik een van die eerste woonhuise vir senior offisiere wat in die kantonnement gebou is. Dit was ook die eerste akkommodasie vir die Unieverdedigingsmag se pasiënte toe dit in November 1915 in 'n 30-bed hospitaal omskep is. Vir dekades het die woning as District House bekend gestaan en het plaaslike bevelvoerders gehuisves. In 1960 is die naam verander.

Aan die noordekant van die huis is ' $n$ wye stoep met hout vloer en pilare. Toe dit in 1962 gemoderniseer is, is die hout wand binne van die lang gang, groot woonkamers en vier slaapkamers behou. So ook die oorspronklike kaggels, wat egter van moderne verwarmers voorsien is. Die komvensters is ' $n$ kenmerkende modegier wat gebruik is in huise vir senior offisiere.

Hierdie huis is ' $n$ tipiese voorbeeld van ' $n$ aantal sink-en-hout konstruksies wat as wonings vir offisiere gebou is. Die oorspronklike vier morg groot tuin was blykbaar nie veel bewerk nie tot 1926 , toe (later genl sir) Pierre van Ryeneveld dit (tot 1949) bewoon het. Kmdt-genl P.H. Grobbelaar het ook ' $n$ aansienlike bydrae tot die ontwikke 
ling van die tuin gelewer en voordat hy daar weg is in 1965, bykans tweehonderd bome aangeplant. ${ }^{44}$ Daarna is die huis vir ongeveer drie jaar lank as kantoor gebruik alvorens dit weer as woonhuis vir It-genl C.A. Fraser ingerig is. ${ }^{45}$ Die huis is die enigste van sy soort wat vir senior offisiere opgerig is wat nog staan. Dit was ook een van die eerste (indien nie die eerste) gebou op Voortrekkerhoogte nie.

Op 'n koppie op die perseel staan 'n blokhuis. Die Britte het hierdie "fire post" gebou op die hoogste oostelike punt van die aanvanklike grense van die kantonnement. Die dubbel sinkplaatwand met 15 skietgate is met klippe gevul. In een stadium is dit as hok vir posduiwe gebruik, maar tydens die Sharpeville krisis in 1960 is hierdie blokhuis ook beman. ${ }^{46}$

\section{Administratiewe Dienskorps Menasie}

Langs Johannes Kochweg is woonhuise vir senior offisiere gebou en in soldatetaal is die straat tot Tin Pan Alley verdoop. Ben Viljoenstraat, wat met 'n T by Johannes Kochweg aansluit, was oorspronklik Lancasterweg. Hier was die Administratiewe Dienskorps se menasie en kwartiere aan die eenkant van die straat gebou en vyf of ses woonhuise vir offisiere aan die anderkant. Junior offisiere het in soortgelyke huise gewoon in Piet Retiefweg (Neville Road na Neville Lyttelton) en Jacobus Naudéstraat (Welch Road). Vier van die huise staan nog ofskoon in 'n erg verwaarloosde toestand. Dit is betreurenswaardig, want kort voor lank sal SuidAfrikaners ver moet soek vir huise met oorspronklike porselein handvatsels en handgerolde glas ruite, soos wat hier die geval is.

Hierdie huise het ook bekende militêre figure gehuisves soos maj E. Barber, kwartiermeester en gesondheidsoffisier van die SA Geneeskundige Diens en kol (later genl-maj) Dan Pienaar, wat bevelvoerder was van 1 SA Divisie in Wêreldoorlog $\|$ toe hy in 'n lugramp gesneuwel het. Die Hoof van Lugstaf vanaf 1 Mei 1965 tot 30 November 1967, It-genl H.J. Martin, het in die jare toe hy nog kolonel was ook daar gewoon.47

Anders as die woonhuise het die menasie nie 'n lang gang nie. Dit het ook uitgeboude skuifraamvensters en nie boogvensters soos huise vir senior offisiere nie. Die gedraaide toringkies op die dak is uniek. Volgens generaal Klopper het die weerlig een van hulle in 1944 getref, maar is spoedig vervang. ${ }^{48}$ Die groot bome op die perseel dateer uit die jare 1924 tot 1926.

Volgens oorlewering het lord Methuen op sy dag vir genl Koos de la Rey in hierdie gebou ontvang en, so word geglo, dat Methuen toe daar gewoon het. Dit is egter baie moontlik dat De la Rey juis daar ontvang is omdat dit 'n offisiersmenasie was. Methuen het in Head Quarters House gewoon.

In later jare is die gebou wel as wooneenheid gebruik. Lt kol Hoare (SALM) wat gedurende Wêreldoorlog II Direkteur-generaal Tegniese Diens by Verdedigingshoofkwartier was, het daar gewoon. So ook vanaf 1 Mei 1942 tot 3 Februarie 1947 die vermaarde genl-maj G.E. Brink (wat genl-maj Dan Pienaar opgevolg het). Die laerskool op Voortrekkerhoogte is na hom vernoem.

Ander bekende inwoners was brig H.B. Klopper, Leërstafhoof en die eerste Kommandant-generaal van die SA Weermag. Ook 'n later waarnemende Kommandant-generaal, It-genl W.R. van der Riet het daar gewoon.

In hierdie gebied met sy woonhuise vir senior offisiere, moes daar aanvanklik baie perdestalle gestaan het. Tans staan slegs een wat op die perseel van die menasie gebou was en wat die verloop van dekades van modernisering en ontwikkeling weerstaan het.

\section{'n Stylvolle voorafvervaardigde hoofkwartier vir die garnisoen}

Die hoofkwartier wat vir die Britse garnisoen opgerig is, het nie 'n treffende styl nie, maar bly nietemin 'n indrukwekkende gebou. Dit is uniek op Voortrekkerhoogte aangesien dit duidelik van meet af gebou was as kantoor en nie stoor of huis nie. 'n Smal stoep loop rondom die oorspronklike gebou wat sonder 'n gang opgerig is. Hierdie is een van die geboue wat volgens oorlewering uit Indië afkomstig was.

Naas die oorspronklike gebou, is van historiese belang twee bauhinias op die westelike grasperk wat volgens oorlewering in 1910 geplant is ter ere van Uniewording. Genl Van Reyneveld se entoesiasme vir tuinmaak is ook hier te sien in die vorm van kareebome (rhus lancea). Aanvanklik was die hele noordelike grens met karee beplant, wat egter in die jare sestig afgekap is 


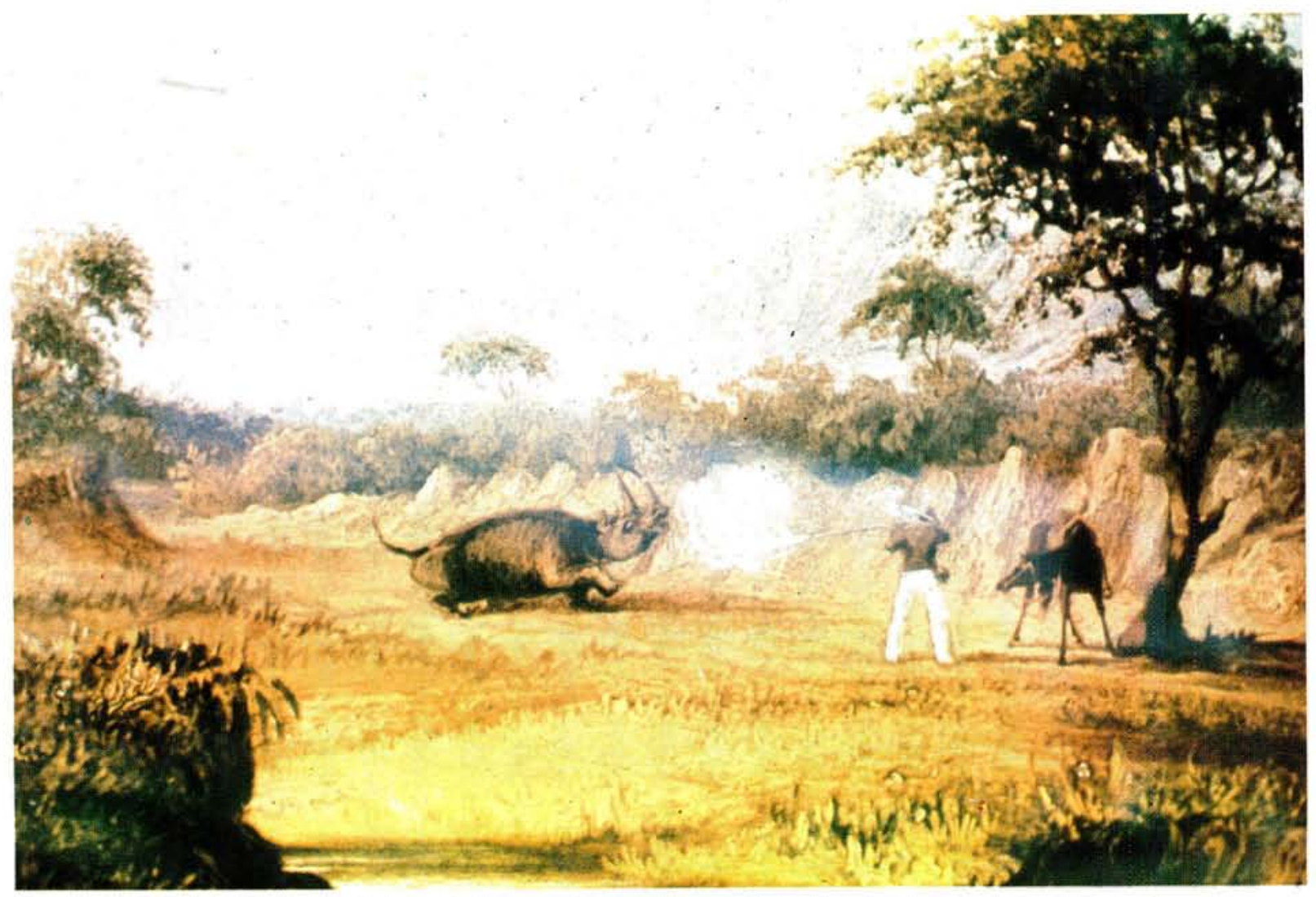

Foto 1 'n Thomas Baines-skildery van 'n renosterjag met die Magaliesberg op die agtergrond.

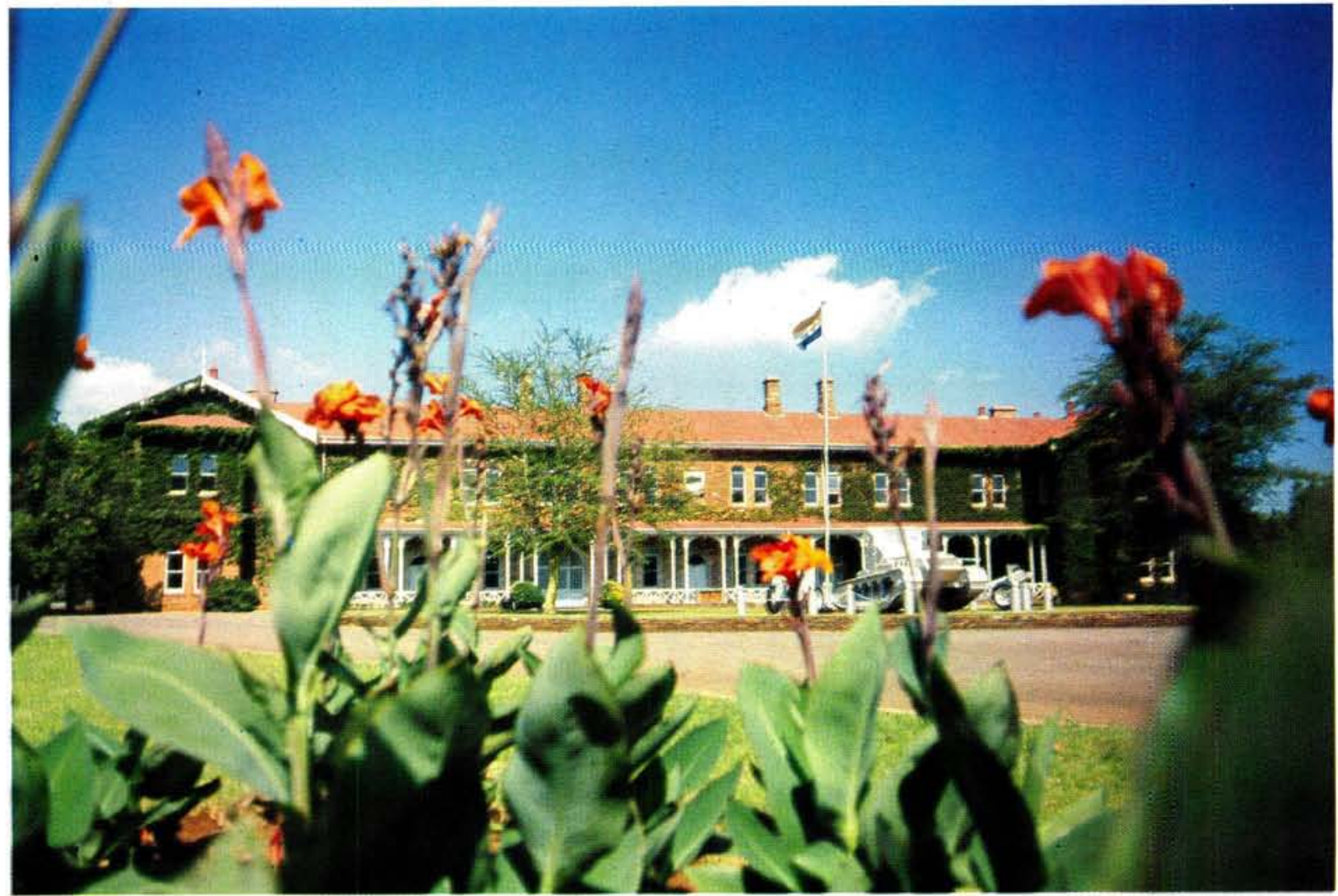

Foto 2 Die oudste permanente konstruksie op Voortrekkerhoogte vorm deel van die SA Leërkollege. 


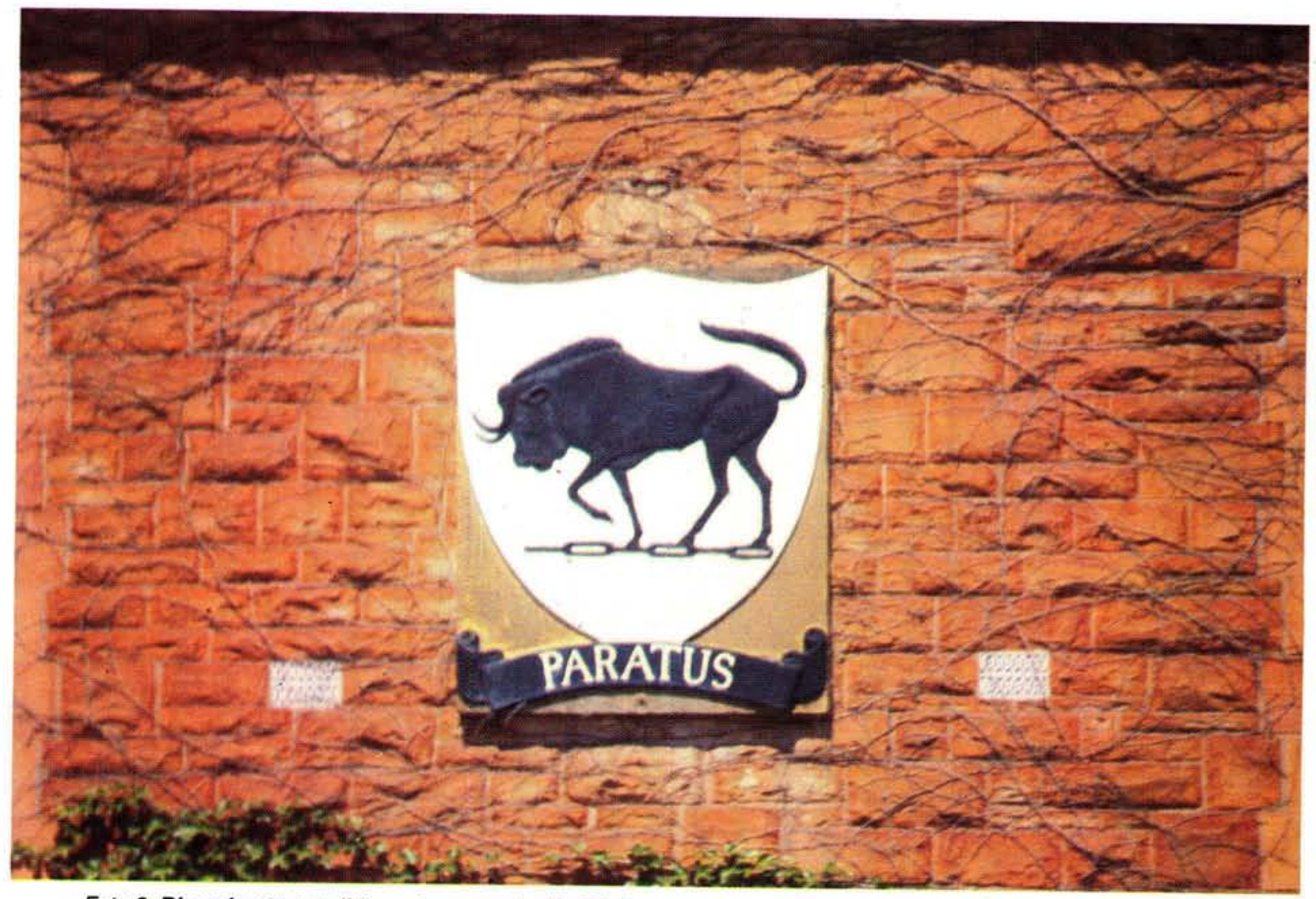

Foto 3 Die gekapte sandklip-gebou waarin die SA Garrison Institute aanvanklik gehuisves was en waar die SA Leërkollege tans is.

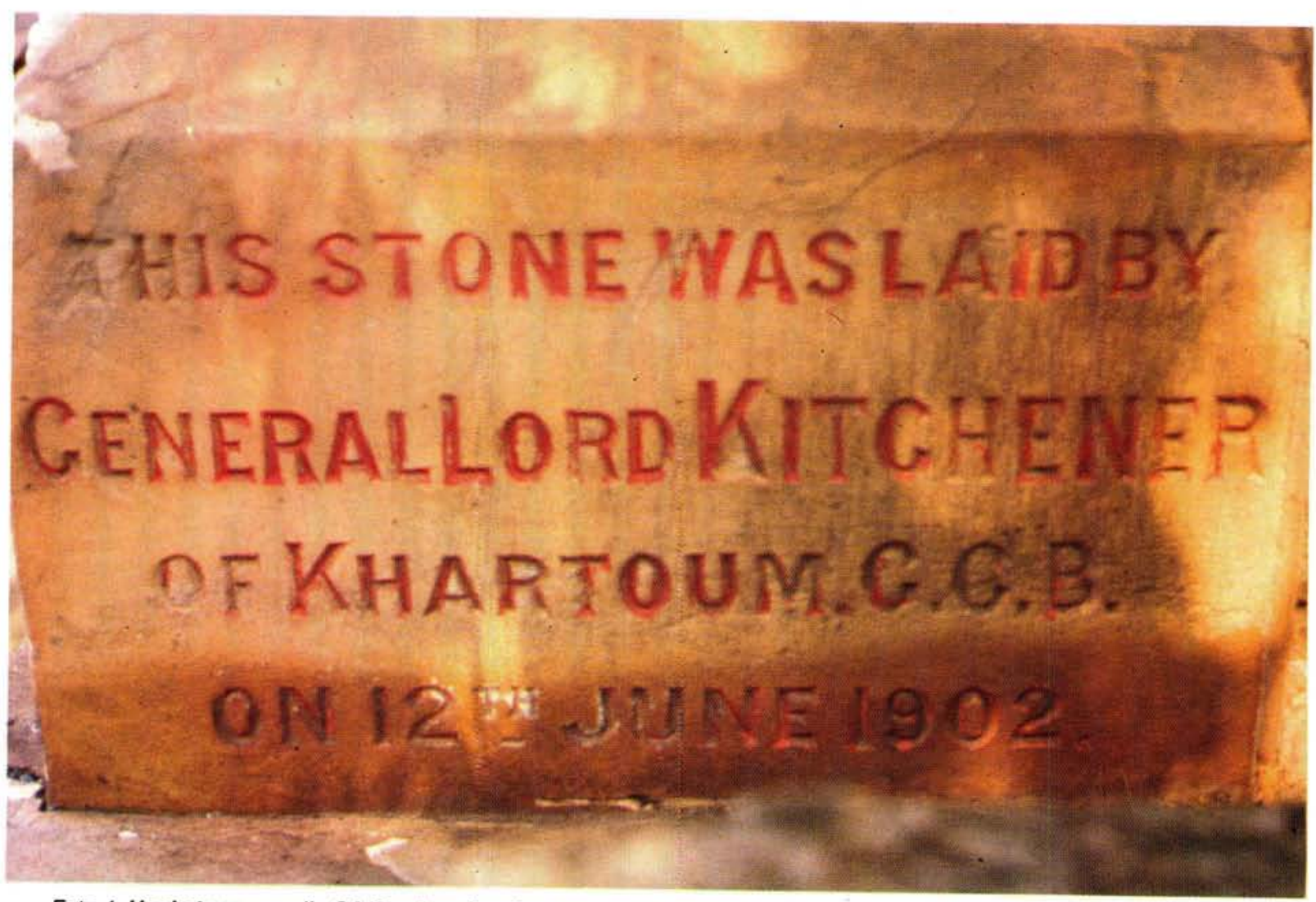

Foto 4 Hoeksteen van die SA Garrison Institute-gebou op 12 Junie 1902 gelê deur lord Kitchener van Khartoem. 


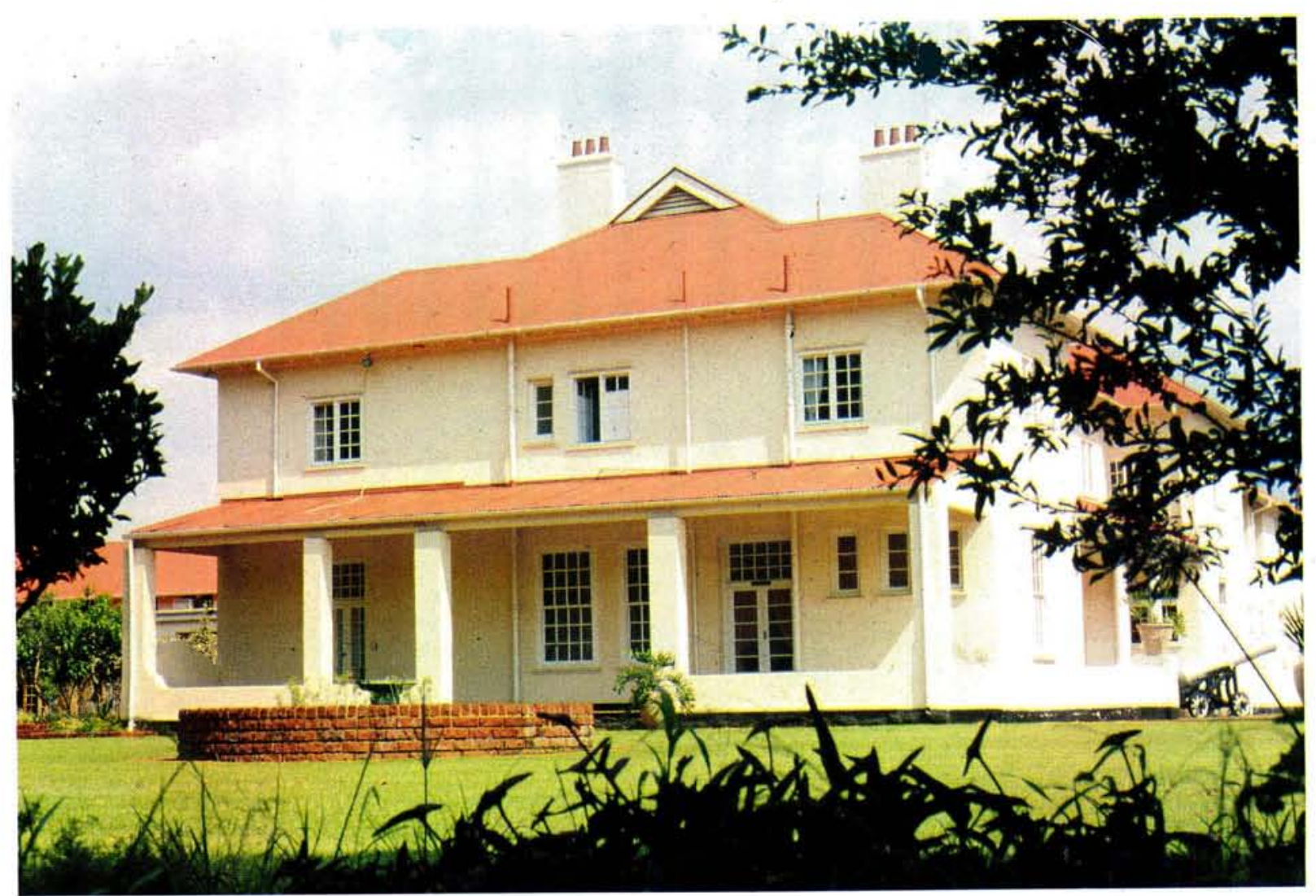

Foto 5 Die huidige SA Lugmag-Offisiersmenasie is in 1903 vir genl sir Neville Lyttelton gebou.

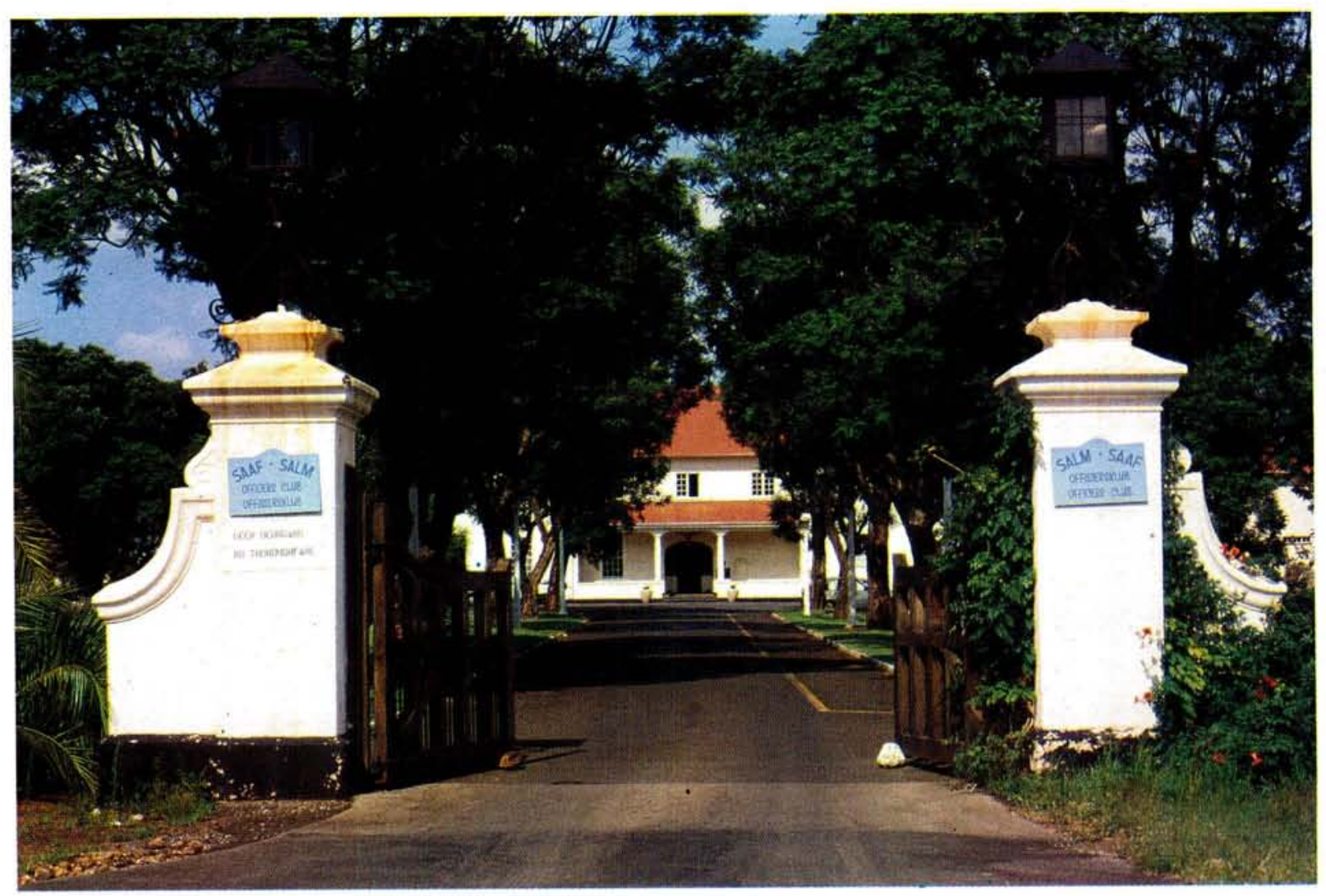

Foto 6 Oprit na die SA Lugmag-Offisiersmenasie wat lank as Head Quarters House bekend was. 


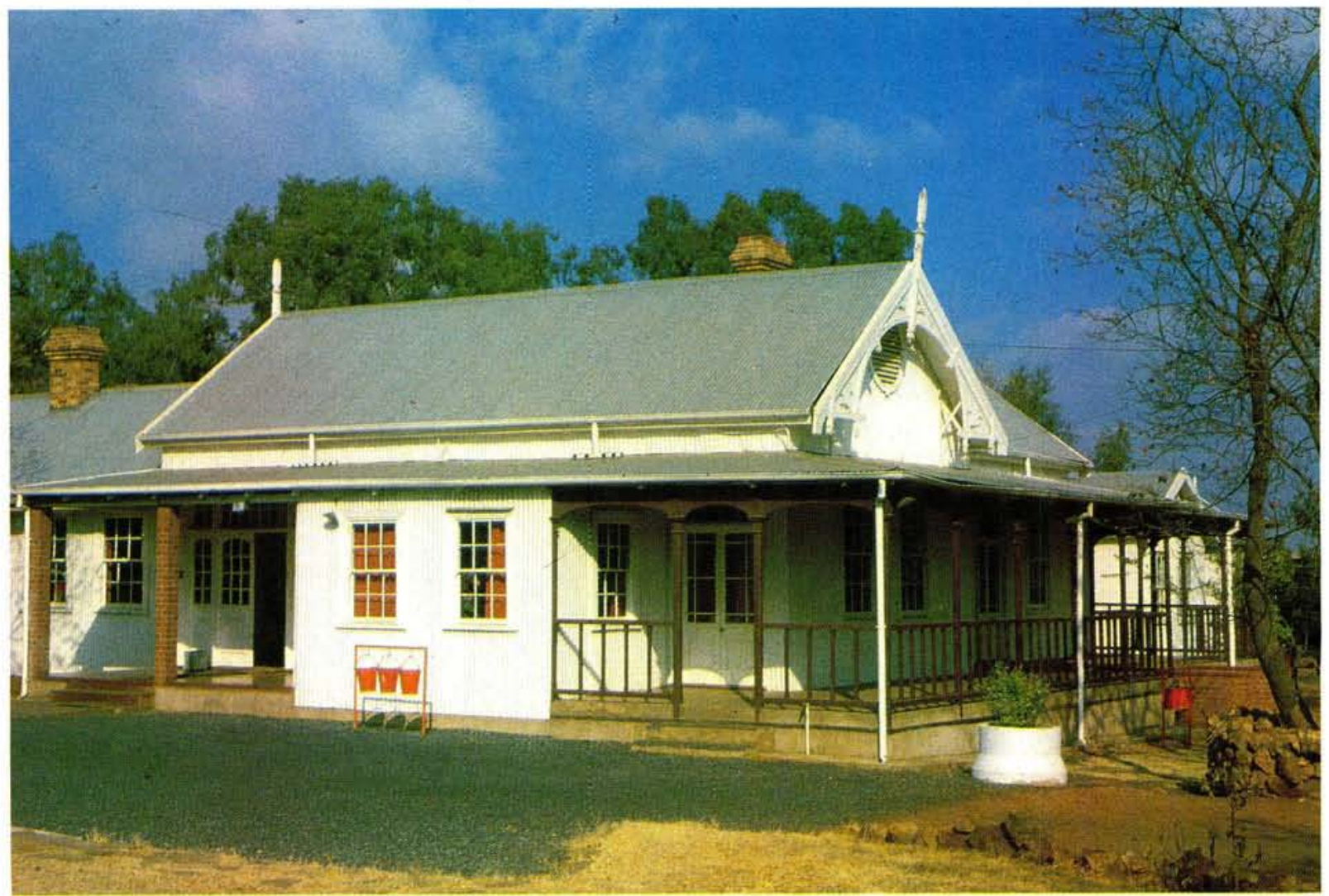

Foto 7 Die gebou in Ben Viljoenstraat is as offisiersmenasie vir Britse soldate opgerig.

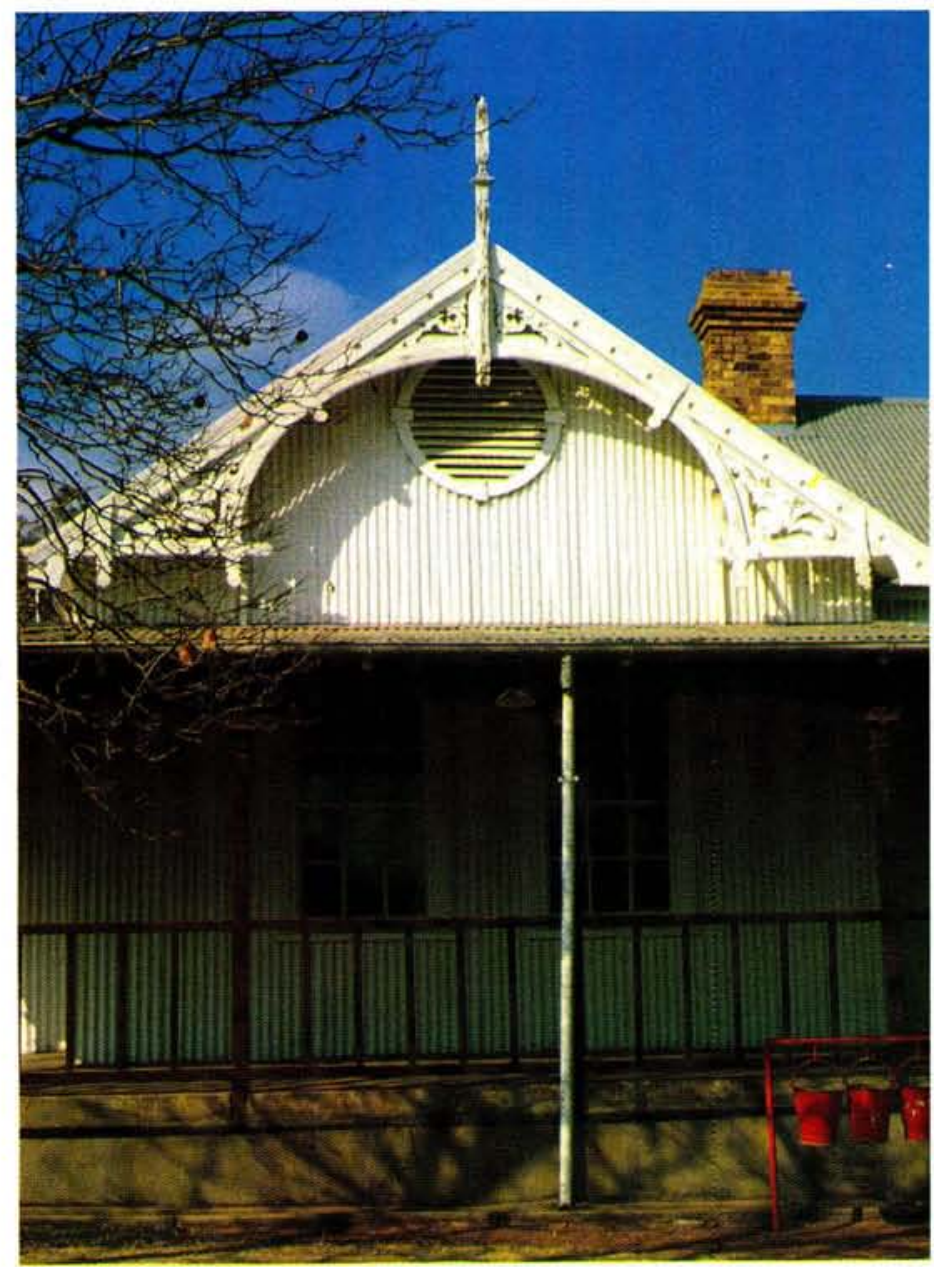

Foto 8 'n Goeie voorbeeld van Victoriaanse hout-sierafwerking van gewels wat goed bewaar is. 


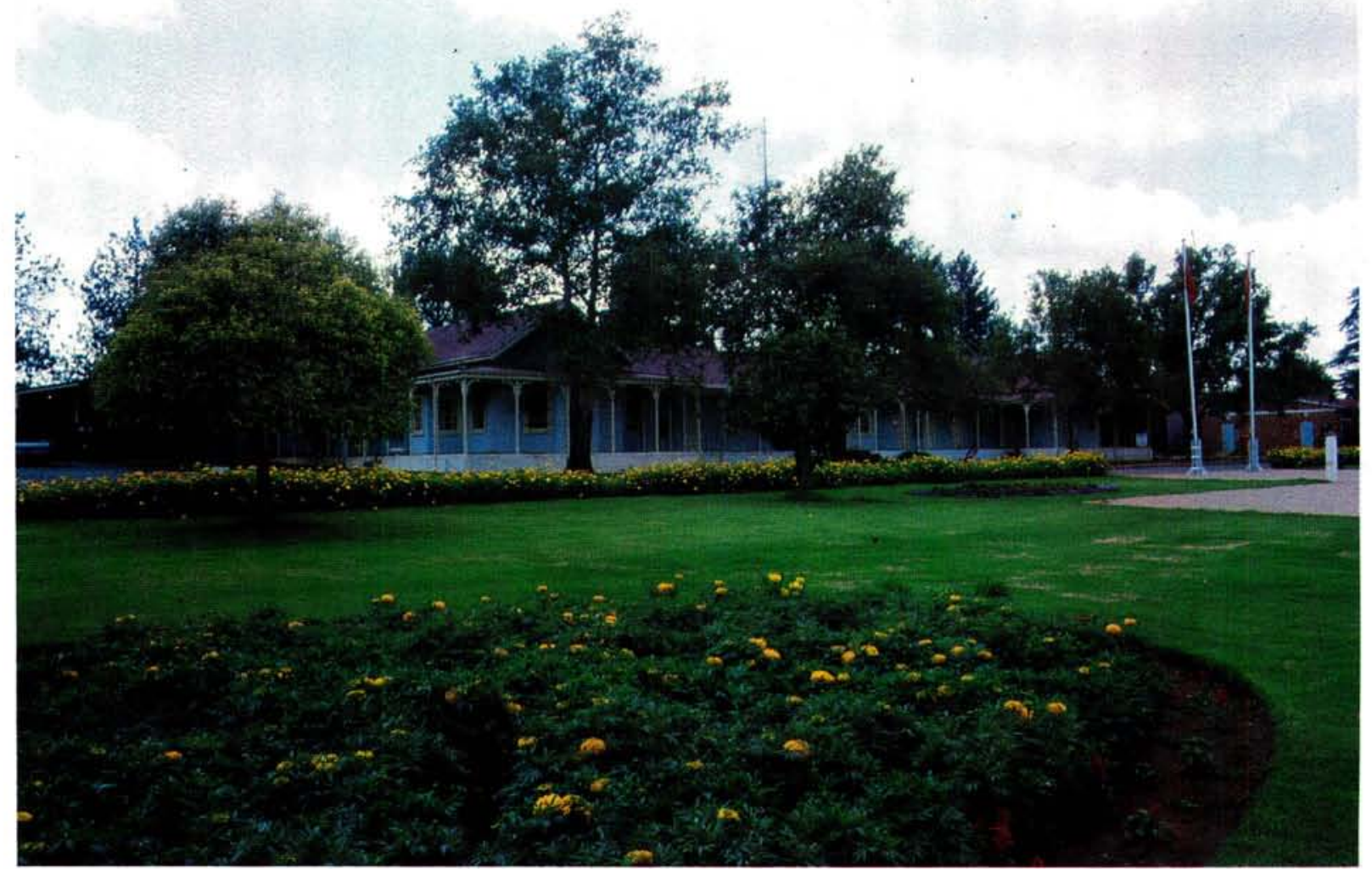

Foto 9 Die hoofkwartiergebou van die Britse garnisoen in Transvaal word steeds as hoofkwartier gebruik.

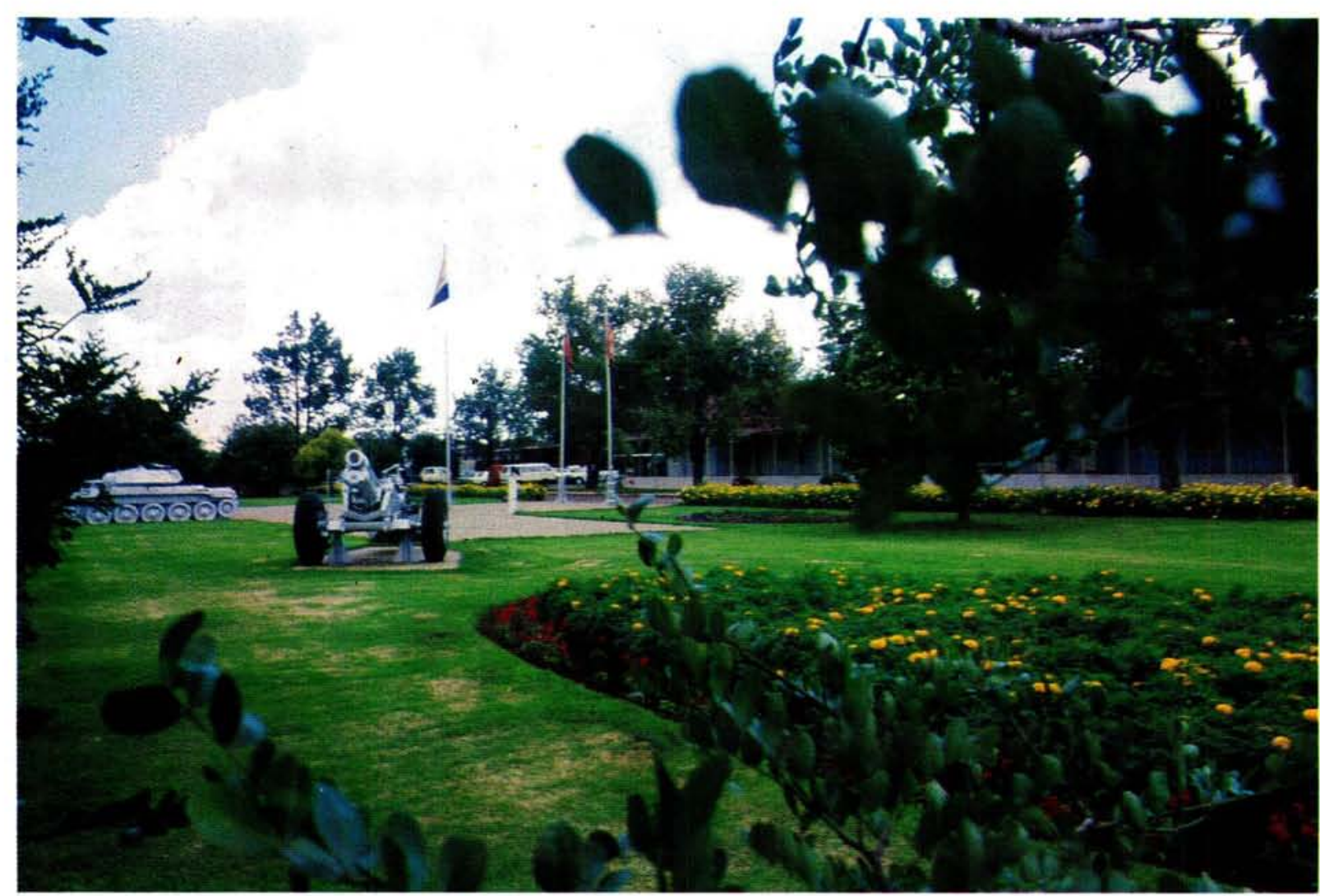

Foto 10 Wapens versier al $\mathbf{5 0}$ jaar lank die grasperk voor die hoofkwartier. 


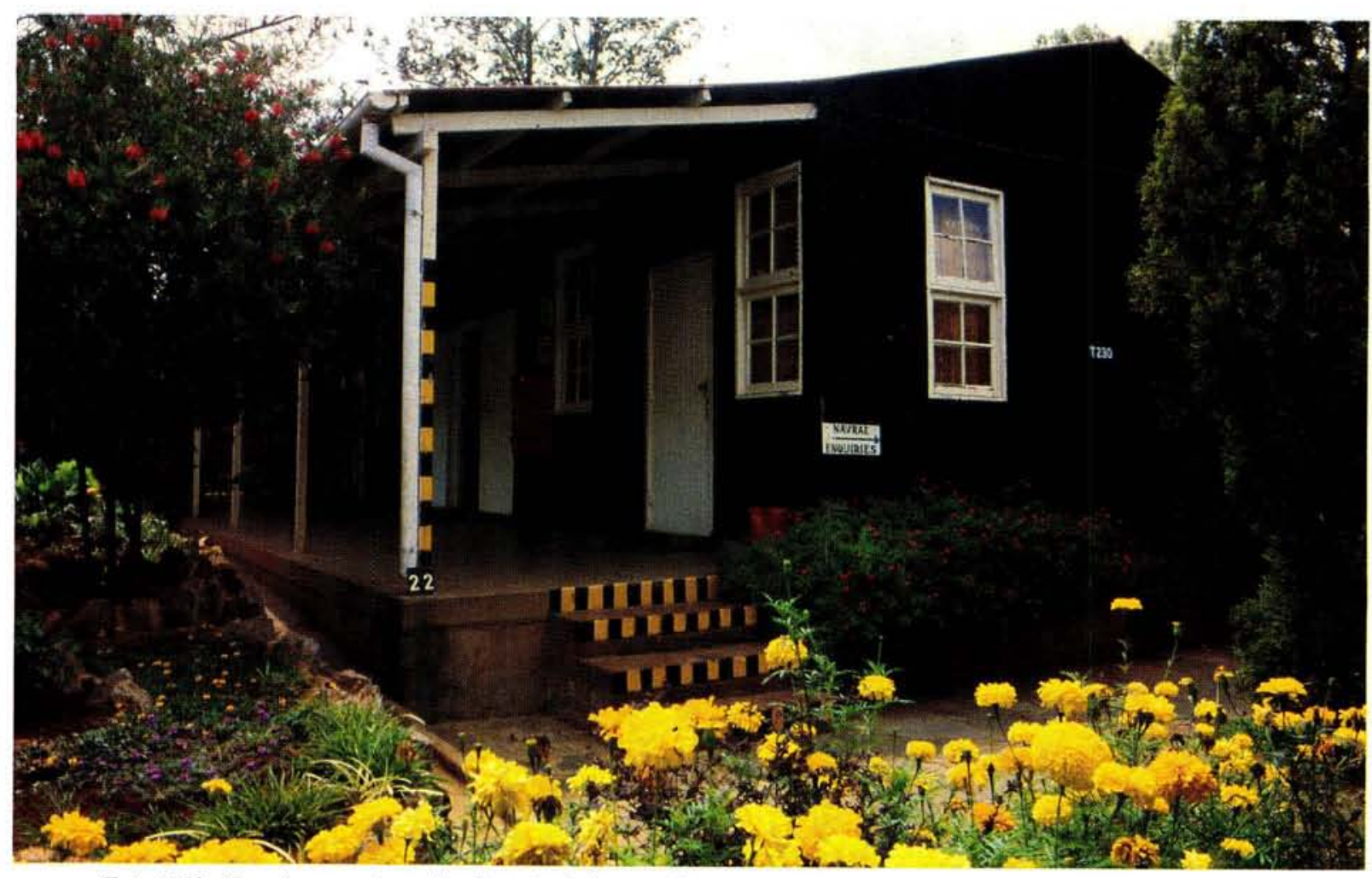

Foto 11 'n Konglomeraat van boukonstruksies op die perseel van Kommandement Noord-Transvaal is verteenwoordigend van hoe daar sedert sy ontstaan op Voortrekkerhoogte gebou is. (Sien ook foto 13 op volgende

bladsy).

Foto 12

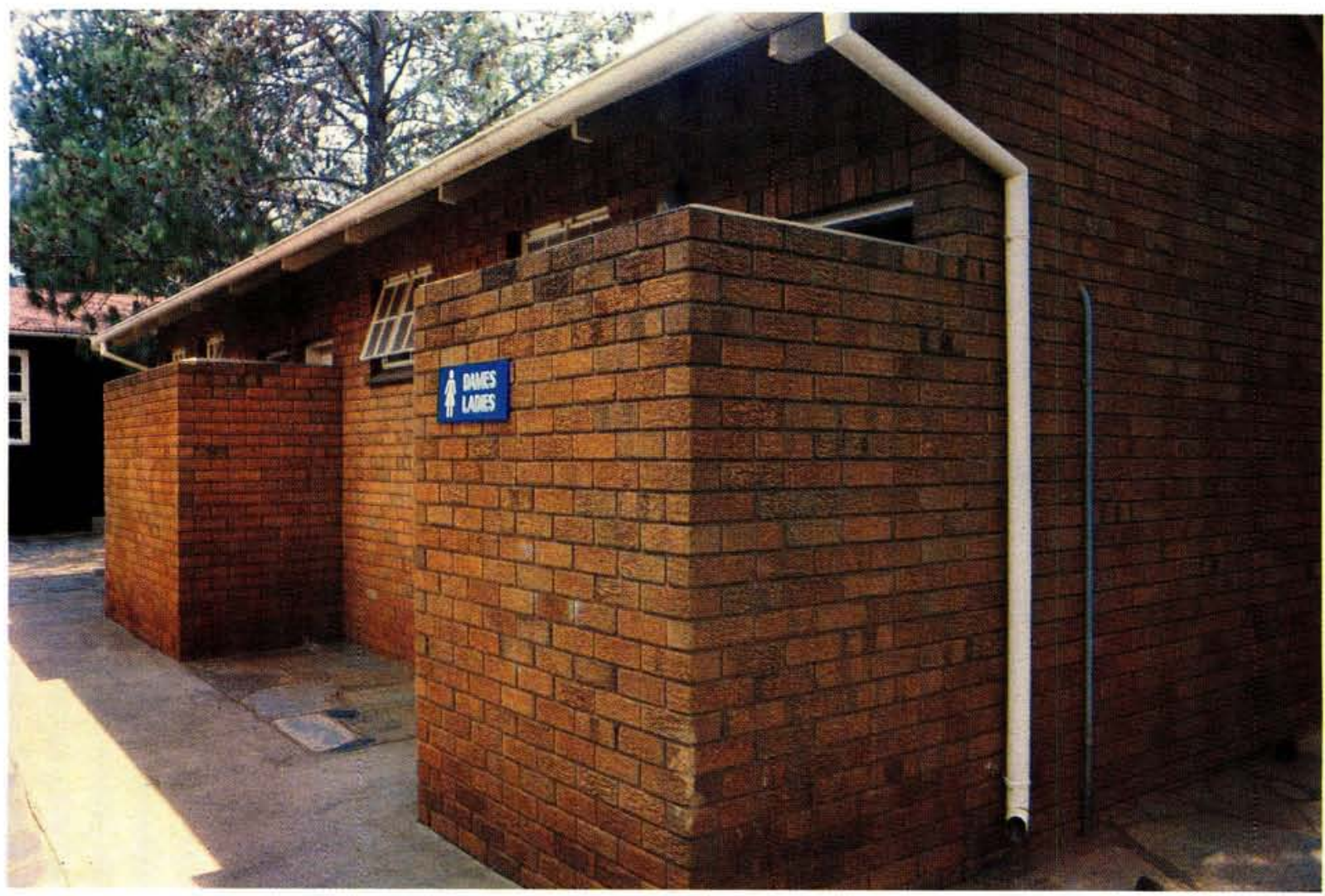




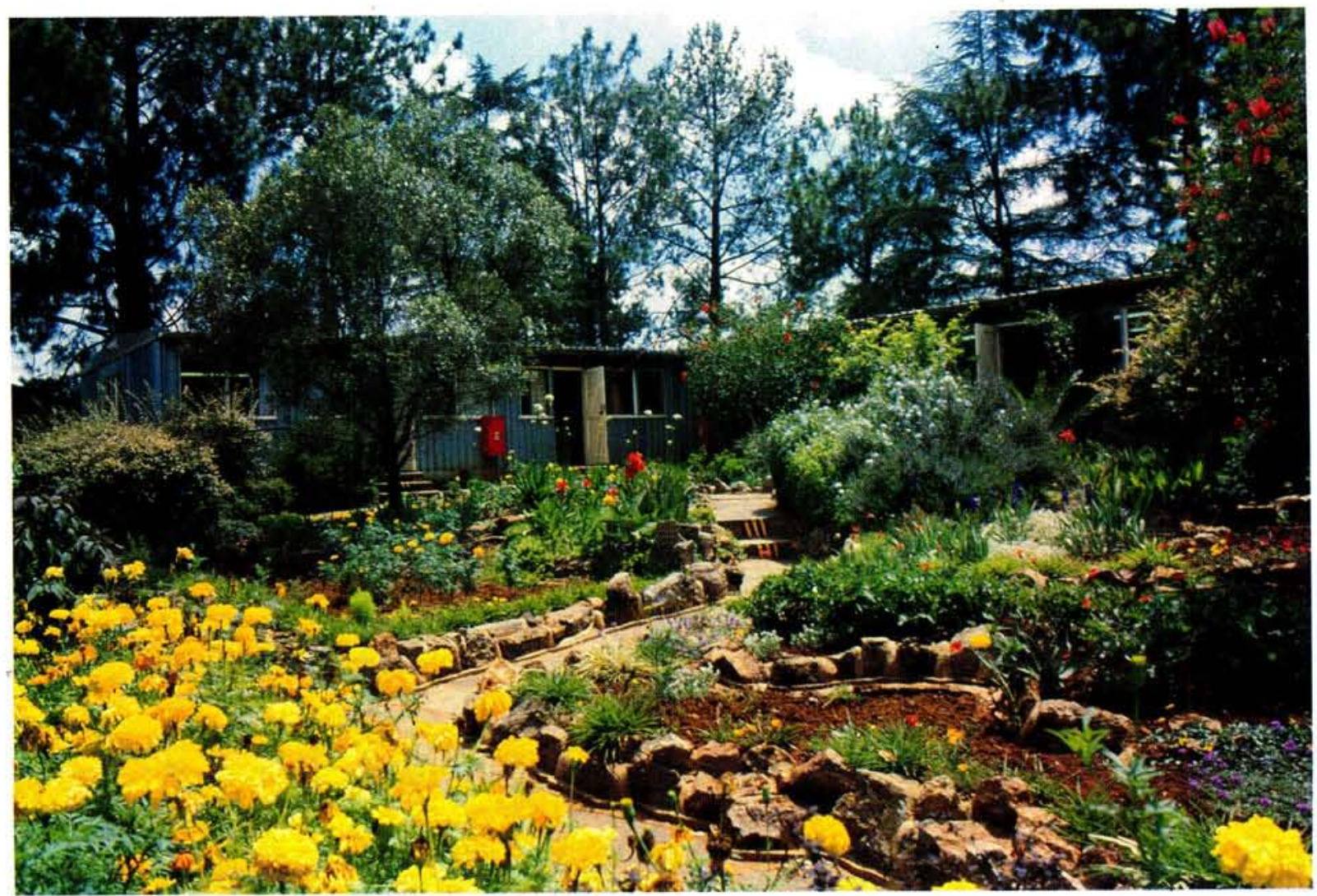

Foto 13 (Sien foto's 11 en 12).

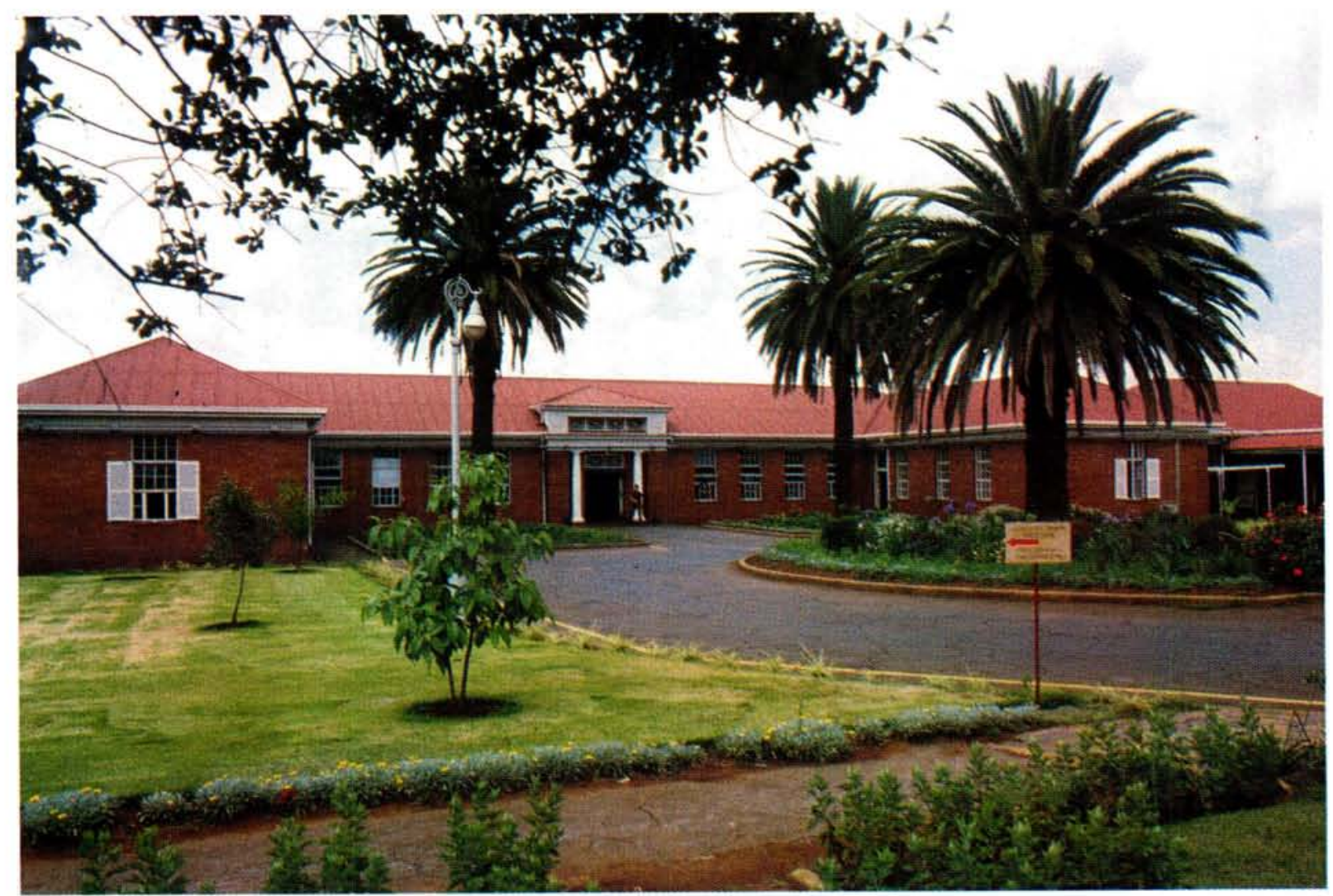


Die wapens wat die grasperke versier het ook 'n geskiedenis van hulle eie. Die eerste wapen wat die hoofkwartier versier het, was 'n Wêreldoorlog I tenk wat tydens Wêreldoorlog II egter weer vir aktiewe diens opgekommandeer is. Sy plek is in 1963 gevul met 'n twee-pond Crusader tenk wat oorspronklik by die Personeeldiensskool gestaan het. Twee ses duim kanonne ('n Merk 17 en Merk 19 onderskeidelik) wat volgens oorlewering in Oos-Afrika by Mogodishu gebruik is, was eers by Sonderwater alvorens hulle na die grasperk voor die hoofkwartier geskuif is en waar dit tans nog staan.

Gedurende die afgelope dekades is talle uitbreidings op die perseel aangebring. Van die eerstes was 'n gebou wat later as onder andere kombuis gebruik is. Oorspronklik was dit vir 'n baie bekende anderskleurige bode in die Voortrekkerhoogte gebied, bekend as "Ou Josef", in $1937-1938$ as woonkwartier opgerig is. Volgens oud-soldate, wat in daardie jare hulle daaglikse brood hier verdien het, was daar toe al sprake van 'n nuwe hoofkwartier elders, maar ' $n$ half eeu later bly dit steeds die versugting van klerke wat in verouderde kantoorruimtes ' $n$ moderne tegnologiese administratiewe era moet bedryf!

Die oorlog het gevolg en etlike ander uitbreidings op dieselfde perseel. Die vleuel oos van die hoofgebou dateer waarskynlik ook uit die tyd van die Britse besetting. 'n Brand het dit gedurende Wêreldoorlog II verwoes maar dit is dadelik weer herbou saam met ' $n$ vleuel aan die noord-oostelike hoek van die kompleks, 'n reeks geboue waarin die vervoerkantoor, store en kleremaker geakkommodeer was, geboue op die suidelike grens van die perseel en 'n permanente konstruksie om die tydelike vleuel suidoos van die hoofgebou te vervang.

In 1949 is ' $n$ voorafvervaardigde vleuel vanaf 1 Militêre Hospitaal verskuif tot noordoos van die hoofgebou. Die stap is gevolg met die verdere oprigting van tydelike geboue in die afgelope twee dekades.

'n Sinkgebou op die perseel was as sel gebruik en die skuur naaste aan die pad, oorspronklik die garage van die Militêre Polisie Hoofkwartier, wat ook hier geakkommodeer was. Die ablusieblok is in 1965 opgerig op dieselfde terrein waar die tydelike konstruksie voorheen gestaan het. ${ }^{49}$

Vanaf die straat bied die hoofkwartier van Kommandement Noord-Transvaal 'n beeld van statige elegansie, maar agter die Victoriaanse front lê 'n bonte mengelmoes konstruksies, soos dobbelsteentjies wat sonder plan in ' $n$ beperkte ruimte uit die dobbelaar se hand gerol het; ' $n$ opset oor dekades heen geskep om akkommodasienood te verlig, want daar was altyd ander prioriteite. In die SA Weermag kom die taak eerste en is akkommodasiebehoeftes hieraan ondergeskik. Daarom is dit so dat, wat aanvanklik gebou is om 'n Britse kantonnement vir 3000 soldate te administreer, sedert daardie eerste jare uitbreidings beleef en talle veranderinge sien kom en gaan het.

Van meet af was die gebou deur Brit en Boer as hoofkwartier vir militêre bevel in Transvaal gebruik. Kmdt-genl H.B. Klopper het vertel dat bevelvoerders meermale hulle hoofkwartier fisies vanaf die SA Garrison Institute se meer statige gebou gehanteer het. Vir ' $n$ kort rukkie in 1930 was die SA Lugdiens se hoofkwartier hier gevestig. Vanaf 1933 is daar begin om ' $n$ onderskeid te tref tussen die Transvaal en Robertshoogte bevelsposte, maar in die praktyk was die twee poste gewoonlik gekombineer tot 17 Oktober 1938. Toe is Transvaal en Robertshoogte bevelsposte gekombineer met bevel oor die hele Transvaal, Witwatersrand en die Mafeking landdrosdistrik uitgesluit. Noordelike Kommandement het op 3 Mei 1946 tot stand gekom.

\section{Voortrekkerhoogte se oudste gemeentes}

Die eerste gemeente was die van padre E.E. Day van die Anglikaanse Kerk. Sy gemeente het ongeveer saam met die SA Garrison Institute, waar dienste gehou is, ontstaan. $\mathrm{Na}$ die onttrekking van die Britse soldate in 1914 het die Unieverdedigingsmag kapelane vir die gemeente, wat steeds ononderbroke bestaan, aangestel. Eredienste is agtereenvolgens gehou in 'n gebou van die Spesiale Diensbataljon (waar die Personeeldiensskool tans is) en ' $n$ buitehuis by die ou 1 Militêre Hospitaal wat $c p 24$ Junie 1934 tot beskikking van die gemeente gestel is. Die gebou is amptelik op 3 Augustus 1934 deur biskop Talbot, biskop van Pretoria, ingewy.

Soos wat die uitbreek van Wêreldoorlog I die onttrekking van Britse soldate in Suid-Afrika tot gevolg gehad het, het Voortrekkerhoogte gedurende Wêreldoorlog II weer 'n toevloei van Britse soldate gesien, veral ten opsigte van lugmag personeel. Die Departement van Verdediging het derhalwe besluit om ' $n$ kerk te bou en ' $n$ student van sir Herbert Baker, J.C. Kerr snr, het die gebou ontwerp. Die gedenksteen van die 


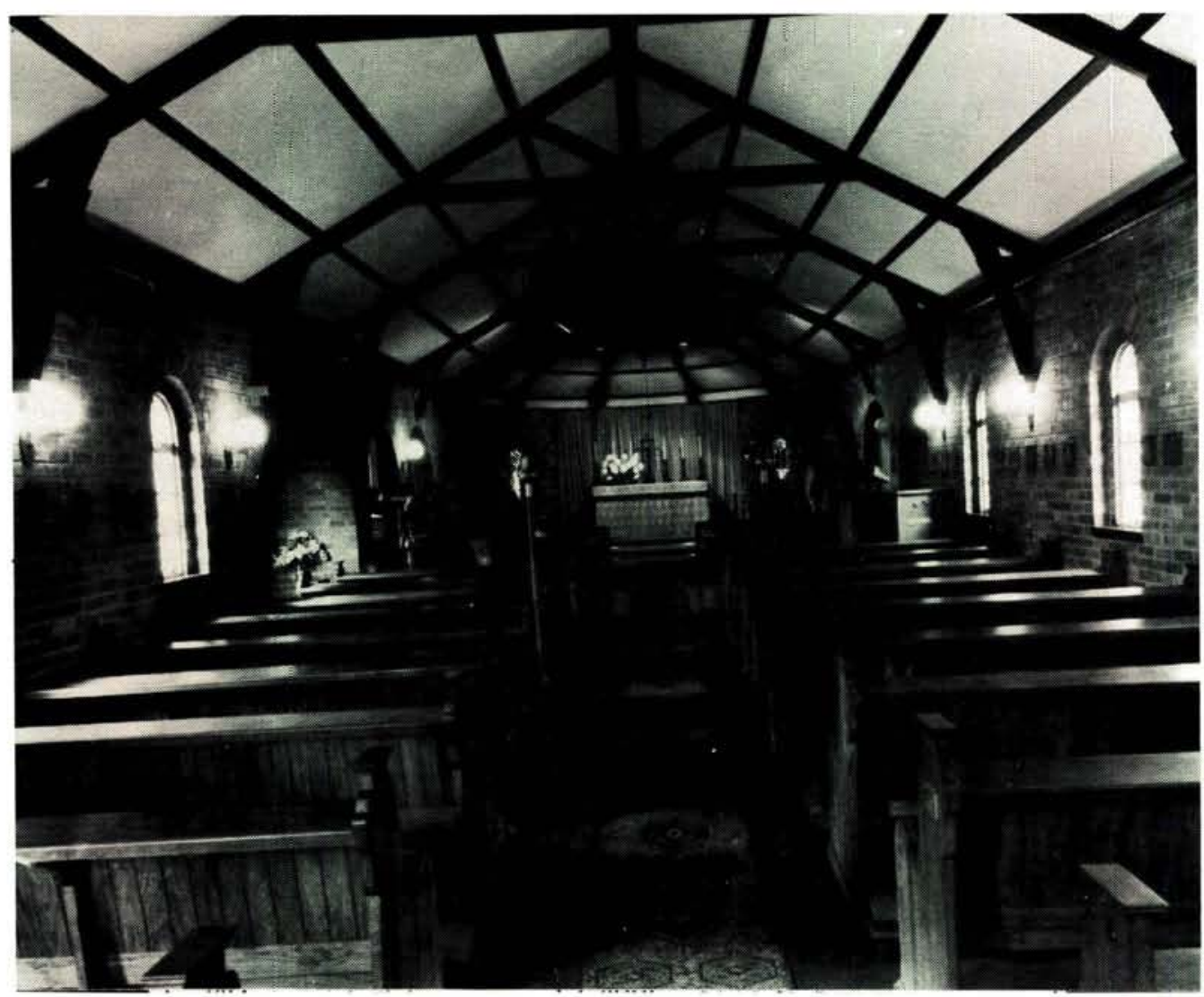

Foto 15 Hlerdle Kerk is gedurende Wêreldoorlog II gebou vir dle oudste gemeente op Voortrekkerhoogte.

pragtige klein kerkie is op 15 Februarie 1942 deur genl-maj H.S. Wakefield gelê, die dag waarop die gebou in gebruik geneem is.

Die oorlog het permanent sy merk op die kerkgebou gelaat. Twee gekleurde glas vensters wat deur Arthur Watson van Johannesburg gemaak is, is op 25 Julie 1943 deur maj A.E. Lorch geïnstalleer ter herinnering aan sy seun wat aan wonde opgedoen in Libië, beswyk het. Die panele stel onderskeidelik "Die Opstanding" en "Die Hemelvaart" voor.

Nog ' $n$ oorlog-erflating is die kerktoring, klok en ingangsportaal, in 1946 geskenk deur Britse soldate wat gedurende die oorlog in Suid-Afrika diens gedoen het. 'n Gedenkplaat by die ingang lees, "This bell and turret were given by British troops in South Africa to commemorate the Comradeship between South African and British soldiers. May this mutual appreciation and understanding continue in time of peace."

Die kerkie huisves kosbaarhede wat oor baie jare geskenk is. Daar is glas vensters, hout en silwer kunswerke, onder andere van die be- faamde silwersmit, Omar Ramsden. Die grootste enkele skenking aan die gemeente is afkomstig uit die garnisoenkerk van Wynberg, Kaapstad, wat in 1936 in onbruik geraak het. Uitrusting is ook aangekoop met fondse wat lady Methuen in Brittanje ingesamel en geskenk het as aandenking aan haar man se verbintenis met die gemeente. ${ }^{50}$

Die eerste Nederduits Gereformeerde gemeente is deur eerwaarde John Adler en later deur ds John Murray, be-arbei. Die eerste voltydse prediker, ds A.G.O. Coertze, is in die vroeë dertiger jare aangestel. Hy het tot 1947 die gemeente bedien.

Aanvanklik was dienste gehou in 'n saal, ' $n$ tydelike konstruksie wat in 1938 gesloop is toe die NG Kerk se gebou ingewy is. In die vroeë vyftigs is ook die Nederduits Hervormde en Gereformeerde gemeentes gestig.

\section{Militêre Hospitaal}

In die tydperk voor Wêreldoorlog I het die Unieverdedigingsmag nie oor die vermoë beskik om 


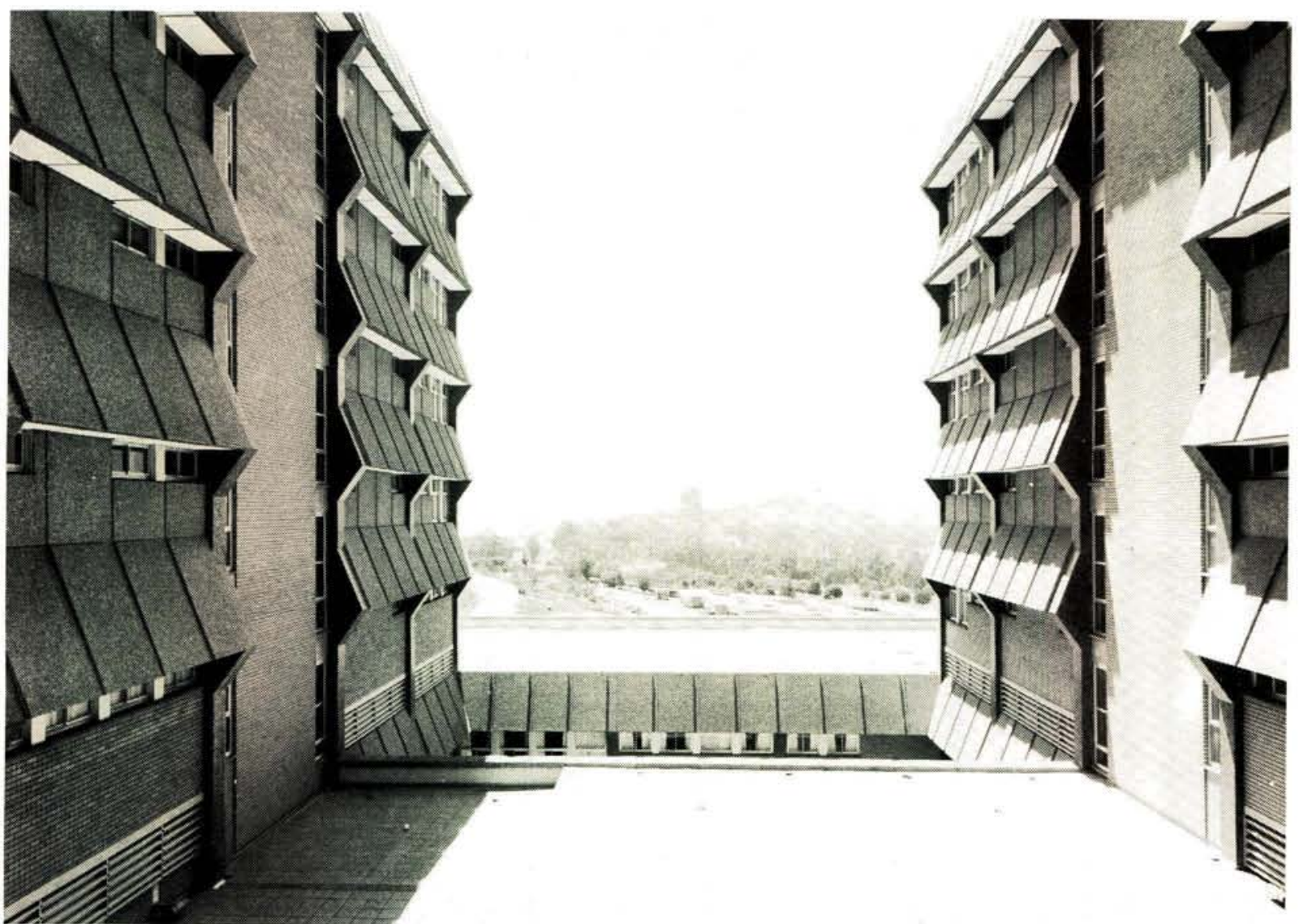

Foto 16 Uitsig vanaf 1 Militêre Hospitaal op die Voortrekkermonument, wat in 1938-1939 verantwoordelik was vir die militêre gebied se naamsverandering.

siek soldate te hanteer nie. Die Britse Royal Army Medical Corps se fasiliteite is instand gehou om na die gesondheid van Britse soldate om te sien. Hoewel die Verdedigingswet van 1912 voorsiening gemaak het vir 'n Suid-Afrikaanse Geneeskundige Diens, was daar teen die einde van 1914 slegs ' $n$ paar bevelsaanstellings gedoen.

Byna onmiddellik nadat die Britse garnisoen na Europa teruggekeer het, is die Royal Army Medical Corps se hospitale te Potchefstroom, Pietermaritzburg, Tempe en ook Robertshoogte gesluit. Soldate in die Pretoria gebied moes van plaaslike burgerlike fasiliteite gebruik maak.

Dit was die posisie toe daar in November 1915 besluit is om Twee Berede Brigade in Pretoria te mobiliseer vir diens in Oos-Afrika. Daar is toe 'n dertig-bed hospitaal in District House ingerig onder bevel van It kol J.H.W. Whitehead. Die mediese personeel vir die bedryf van die hospitaal is in Lytteltonweg 5 en 6 gehuisves.

Ruim ' $n$ jaar later was dit nodig om die fasiliteite uit te brei. veral ten opsigte van 'n hersteloord vir langtermyn pasiënte. Gevolglik is 4 Algemene Hospitaal op 6 Desember 1916 geopen, ook toegerus met District House se uitrusting, personeel en pasiënte.

Die veldtog in Oos-Afrika het daarvoor gesorg dat die nuwe hospitaal vinnig moes vergroot sodat plaaslike offisiersmenasies en kasernes ook in sale omskep is totdat 1600 beddens beskikbaar was. In 'n hersteloord was daar 'n verdere 2000 pasiënte welke getal gaandeweg verminder is totdat die oord op 15 Maart 1918 gesluit is.

4 Algemene Hospitaal se naam is op 1 April 1921 verander na Militêre Hospitaal Robertshoogte, welke naam dit gedra het totdat Wêreldoorlog II en verhoogde militêre aktiwiteite tot die uitbreiding van mediese fasiliteite aanleiding gegee en die naam na 1 Militêre Hospitaal Voortrekkerhoogte verander is. $\mathrm{Na}$ die oorlog is die naam wat dit steeds dra, op 1 April 1947 daaraan toegeken.

Soos elders is daar ook by die hospitaal tussen die wêreldoorlogjare beter fasiliteite geskep. In 
Oktober 1930 het prinses Alice 'n nuwe hospitaal geopen. Die fasiliteite was dus beskikbaar toe hierdie hospitaal gedurende $1945-1946$ in een jaar 10000 pasiënte moes hanteer. ${ }^{51}$

Die SA Geneeskundige Diens was weer eens in 1982 in die bevoorregte posisie om moderne hospitaalgeriewe op Voortrekkerhoogte te kry. Dit het saamgeval met ' $n$ verhoogde stryd in Suidwes-Afrika wat weer ' $n$ toename in pasiënte beteken het.

\section{Epiloog}

Soos 1 Militêre Hospitaal, is baie van Robertshoogte se eerste geboue vervang met permanente konstruksies. Tog het genoeg van die tydelike voorafvervaardigde konstruksies die toets van die tyd weerstaan om aan Voortrekkerhoogte sy unieke karakter te gee. Tydelike en permanente konstruksies wissel mekaar af as bewys van 90 jaar se militêre eise wat gestel is. Daar is tydelike konstruksies opgerig vir garnisoentroepe, tydelike konstruksies opgerig vir twee wêreldoorloë se akkommodasiebehoeftes, permanente konstruksies wat tussen die oorloë opgerig kon word afgewissel met tydelike en permanente konstruksies vir die behoeftes van die huidige konflik in Suider-Afrika.

Terselfdertyd is ' $n$ wye verskeidenheid basisaktiwiteite daar beleef. Gedurende 'n wêreldoorlog het beide bondgenote en vyandelike soldate die strate bewandel wat onlangs onder ' $n$ terroriste vuurpyl deurgeloop het. As kommandementshoofkwartier vir ' $n$ groot gedeelte van Transvaal, word omvangryke militêre aksies steeds effektief georkestreer vanaf die perseel waar die eerste hoofkwartier vir die streek vroeg in die twintigste eeu gebou is, al word daar al 'n halfeeu lank beplan vir 'n nuwe hoofkwartier.

* Kmdt Sophia du Preez, M.A., D.Phil (Pretoria), is verbonde aan die Direktoraat Openbare Betrekkinge.

\section{Bronnelys}

1. W.C. Harris, The wild sports of Southern Africa, Londen, 1938; H.W. Struben. Recollections of adventures 1850-1911, (1920) Kaapstad. p29.

2. J.C.D. Lambrecht, "Voortrekkerhoogte - 'n Geskiedkundige oorsig," Pretoriana, 1960, p108.

3. S.P. Engelbrecht, "Pretoria - Die eerste halfeeu," Pretoria 1855-1955, p2; Sophia du Preez, "Die eerste bewoners van Kerkplein, Pretoria," Contree, no 3, Januarie 1978, p5.

4. TAB: CS 91: 4896, Memorandum, The Municipality of Pretoria Transvaal Administration Board," 17 Mei 1902.

5. TAB: CS 91: 1896, De locale Wetten en Volksraadbes/uiten der ZAR 1896.

6. Sophia du Preez, Vredespogings gedurende die Anglo-Boereoorlog tot Maart 1901, ongepubliseerde MA verhandeling, pp78-79.

7. TAB: CS 86: Verslag, Sekretaris regsdepartement Pretoria, 12 Maar 1902.
8. TAB: CCP 2/86, brief, Pretoria Townlands Committee - Stadsraad, 17 Julie 1905

9. TAB: CS 91: 4896.

10. E.F.W. Gey van Pittius, "Munisipale bestuur in Pretoria: 'n geskiedkundige 0orsig," Pretoria 1855-1955, p58.

11. Ordinance 14/1904, To regulate the ownership of Townlands.

12. F.J. du T. Spies, "Bladsye uit die militêre geskiedenis van Pretoria," Pretoria 1855-1955, pp104-106.

13. J.C.D. Lamprecht, "Voortrekkerhoogte. 'n Geskiedkundige oorsig," Pretoriana, (1960) p108

14. Ibid., p197; F.J. du T. Spies, "Bladsye uit die militêre geskiedenis van Pretoria," Pretoria 1855-1955, p107.

15. AB: MGP 273, inlae 285, naamlys, 16 Junie 1902

16. TAB: CCP: 2/85, sub-lêer, Town Lands: Akteskantoor, Pretoria.

17. Sophia du Preez, "Die val van Pretoria," Militaria, no 5/3, p32.

18. Official History of the War in South Africa compiled by direction of His Majesty's Government, (Londen 1908), pp96-97; H.H. Wilson; With the flag to Pretoria, vol II, (Londen 1901), p673; C.G.S. Sandberg, Twintig jaren onder Kruger's Boeren in voor en tegenspoed, (Amsterdam 1943), p309.

19. TAB: CCP 2/96: 175, brief, genl-maj E. Wood - Pretoria Munisipaliteit, 5 Julie 1902

20. TAB: A433-A434: Fotokopie Kitchener's Papers, diverse briewe vanat Desember 1900-Maart 1902, Kitchener - Brodrick.

21. Tydens die oorlog is sowat 8000 blokhuise gebou wat oor meer as $5600 \mathrm{~km}$ gestrek het. Sien Sophia du Preez, Die Vrede van Vereeniging, ongepubliseerde proetskrif, p18.

22. TAB: CS88: 4479/02, brief, Transvaal Administration - Col Curtis, SAC Johannesburg, 21 Mei 1902.

23. TAB: CS89: 4659/02, aanbevelings, kommissie van ondersoek na staatsgeboue en behuising vir amptenare in Johannesburg, 8 April 1902.

24. TAB: CS89; 4659/02, korrespondensie, 8 April 1902.

25. TAB: CCP43/196-44-03, brief, It-kol W.A.S. Clair - Munisipaliteil Pretoria, 4 Mei 1903.

26. Phyllis Scarnell Lean, One man in his time, (Johannesburg 1964).

27. SAWA: Lêer geskiedenis van Voortrekkerhoogte, Interim report, pp1-6, mededelings padre J.H. Gurney en maj J.S. Fourie wat beide vanaf 1938 lank in Voortrekkerhoogte gewoon en gewerk het.

28. SAWA: Lèer geskiedenis van Voortrekkerhoogte, Interim report, p6.

29. Sophia du Preez, Die vrede van Vereeniging, ongepubliseerde proefskrif, p155.

30. Pretoria News, 10 Julie 1903, p5.

31. SAW Kaarteversameling.

32. J.C.D. Lamprecht, "Voortrekkerhoogte. 'n Geskiedkundige oorsig," Pretoriana, (1960), p110.

33. NASKOM Argief, Korrespondensielêers, Voortrekkermonumentmuseum 1948.

34. J.C.D. Lamprecht, op. cit., p111.

35. SAWA: Lêer Geskiedenis Voortrekkerhoogte, Interim report, p1. Volgens kmdt-genl Klopper is die voorstel gemaak aan die Minister van Verdediging, Oswald Pirow. Kemp was egter in 1938 waarnemende Minister van Verdediging. Sien F.J. du T. Spies, op. cit., p109.

36. SAWA: Lêer Geskiedenis van Voortrekkerhoogte, Interim report, p1.

37. F.J. du T. Spies: Op. cit., p108.

38. SAWA: Lêer Geskiedenis van Voortrekkerhoogte, Interim report; J.C.D. Lamprecht, Op. cit., pp.109-111.

39. F.J. du T. Spies, Op. cit., p.108.

40. General Sir Neville Lyttelton, Eighty years soldiering, politics, games, p.268.

41. The Dictionary of National Biography, founded in 1882 by George Smith.

42. SAWA: Lêer Geskiedenis van Voortrekkerhoogte, Tweede Verslag. p.9.

43. SAWA: Lêer Geskiedenis van Voortrekkerhoogte, Tweede Verslag, pp. $10-11$

44. Transvaler, 25 September 1964, p.17.

45. Kmdmt N-Tvl Argief, Lêer Historiese Data, kwartiermeester, Register, Buildings at Roberts Heights, 1922.

46. SAWA: Lêer Geskiedenis van Voortrekkerhoogte, mededeling van kmdtgenl Klopper.

47. Kmdmt N-Tvl Argief, kwartiermeester, Register, Buildings Roberts Heights, 1922

48. SAWA: Lêer Geskiedenis van Voortrekkerhoogte, Interim report, p.18.

49. SAWA: Lêer Geskiedenis van Voortrekkerhoogte, Interim report, pp.10-14.

50. Parish of Christ the King Voortrekkerhoogte, 1902-1907, J.C.D. Lamprecht, Op, cit., p.105.

51. SAGD OSKO Historiese lêer, manuskrip, "Die geskiedenis van 1 Militêre Hospitaal," 